\title{
Possible Role of Phosphatidylcholine and Sphingomyelin on Fumonisin B1-mediated Toxicity
}

\author{
Yasushi Yamazoe $^{1}$, Noriko Koyama ${ }^{1}$ and Susumu Kumagai ${ }^{1,2}$ \\ ${ }^{1}$ Food Safety Commission, Cabinet Office, Government of Japan \\ Akasaka Park BIdg 22F, 5-2-20 Akasaka, Minato-ku, Tokyo 107-6122, Japan \\ 2 Graduate School of Agricultural and Life Sciences, The University of Tokyo, \\ Yayoi 1-1-1, Bunkyo-ku, Tokyo 113-8657, Japan
}

\begin{abstract}
A major corn-related mycotoxin, fumonisin B1 (FB1), continues to attract attention of researchers as well as risk-assessors due to the diverse toxicological characteristics, including distinct target tissues in different animal species and opposite susceptibility in males and females in mice and rats. More than thirty years passed since the structure identification as a sphingoid-like chemical, but the causal mechanism of the toxicity remains obscure in spites of extensive studies. Considerable amounts of knowledge have been accumulated on the biochemical/toxicological actions of FB1, but the influence on lipid dynamics and mobilization in the body has not been focused well in relation to the FB1-mediated toxicity. Considerable influences of this toxin on mobilization of sphingolipids and phospholipids and also on adaptive changes in their compositions in tissues are implicated from recent studies on FB1-interacting ceramide synthases. Accumulated patho-physiological data also suggest a possible role of hepatic phospholipid on FB1-mediated toxicity. Thus, a mechanism of FB1-mediated toxicity is discussed in relation to the mobilization of phospholipids and sphingolipids in the body in this context.
\end{abstract}

Key words: mycotoxin in foods, phospholipid mobilization, ceramide, sphingomyelin, species difference in target tissues, sex-related difference in susceptibility

\section{Introduction}

Fumonisins are isolated as mycotoxins from cultures on corn of Fusarium verticillioides (moniliforme) ${ }^{1-3)}$. Fumonisin $\mathrm{B}^{4)}$ (FB1*, Fig. 1) has an IUPAC name of (2R,2’R)-2,2'-[[(5R,6R,7S,9S,11R,16R,18S,19S)-19-amino11,16,18-trihydroxy-5,9-dimethyl-6,7-icosanediyl]bis[oxy(2oxo-2,1-ethanediyl)]]disuccinic acid $\left(\mathrm{C}_{34} \mathrm{H}_{59} \mathrm{NO}_{15}, \mathrm{Mw} 721.83\right)$.
This chemical is soluble in water and stable at room temperature and to light. FB1 has values of $\log P$ is 2.20 and $\log D$ at pH 7.4 is -3.88 . The acid part, also called as carballylic acid, has a chelating capability with metals of divalent cations ${ }^{5,6}$. This chemical is known to inhibit sphinganine/sphingosine $\mathrm{N}$-acyltransferase (ceramide synthase/CerS), causing an accumulation of sphingoid bases (IC50 $\sim 75 \mathrm{nM})^{7}$ ), and also inhibits protein phosphatases (PP); $\mathrm{IC}_{50}$ values are 80,300 ,

Received: 6 June 2017; Accepted: 29 August 2017; Published online: 29 September 2017

Corresponding author: Yashushi Yamazoe, Food Safety Commission, Cabinet Office, Government of Japan, Akasaka Park Bldg 22F, 5-2-20 Akasaka, Minato-ku, Tokyo 107-6122 Japan (yamazoe@m.tohoku.ac.jp)

The contents of this article reflect solely the view of the author(s).

Conflict of interest statement: The authors had no conflicts of interest to declare in this article.

Abbreviations: ALP, alkaline phosphatase; ALT, alanine aminotransferase; AST, aspartate aminotransferase; BUN, blood urea nitrogen; C1-unit, one carbon unit; CCT $\alpha$, CTP:phosphocholine cytidylyltransferase $\alpha$; CDE, choline-deficient; ethionine-supplemented; CerS, ceramide synthase; DAG, diacylglycerol; ED, embryonic day; FB1, fumonisin B1; GD, gestational day; GPI, glycosylphosphatidylinositol; HDL, high-density lipoprotein; LC/MS, liquid-chromatography mass-spectrometry; LPA, lysophosphatidic acid; Mrp, multidrug resistance-associated protein/ABCC transporter; NTD, neural tube defect; PC, phosphatidylcholine; PE, phosphatidylethanolamine; Pemt, phosphatidylethanolamine N-methyltransferase; P-gp, p-glycoprotein/MDR1/ABCB1 transporter; PLA2R, phospholipase A2 receptor; PP, protein phosphatase; SD, Sprague-Dawley; sPLA2, secretory phospholipase A2; SMS, sphingomyelin synthase 

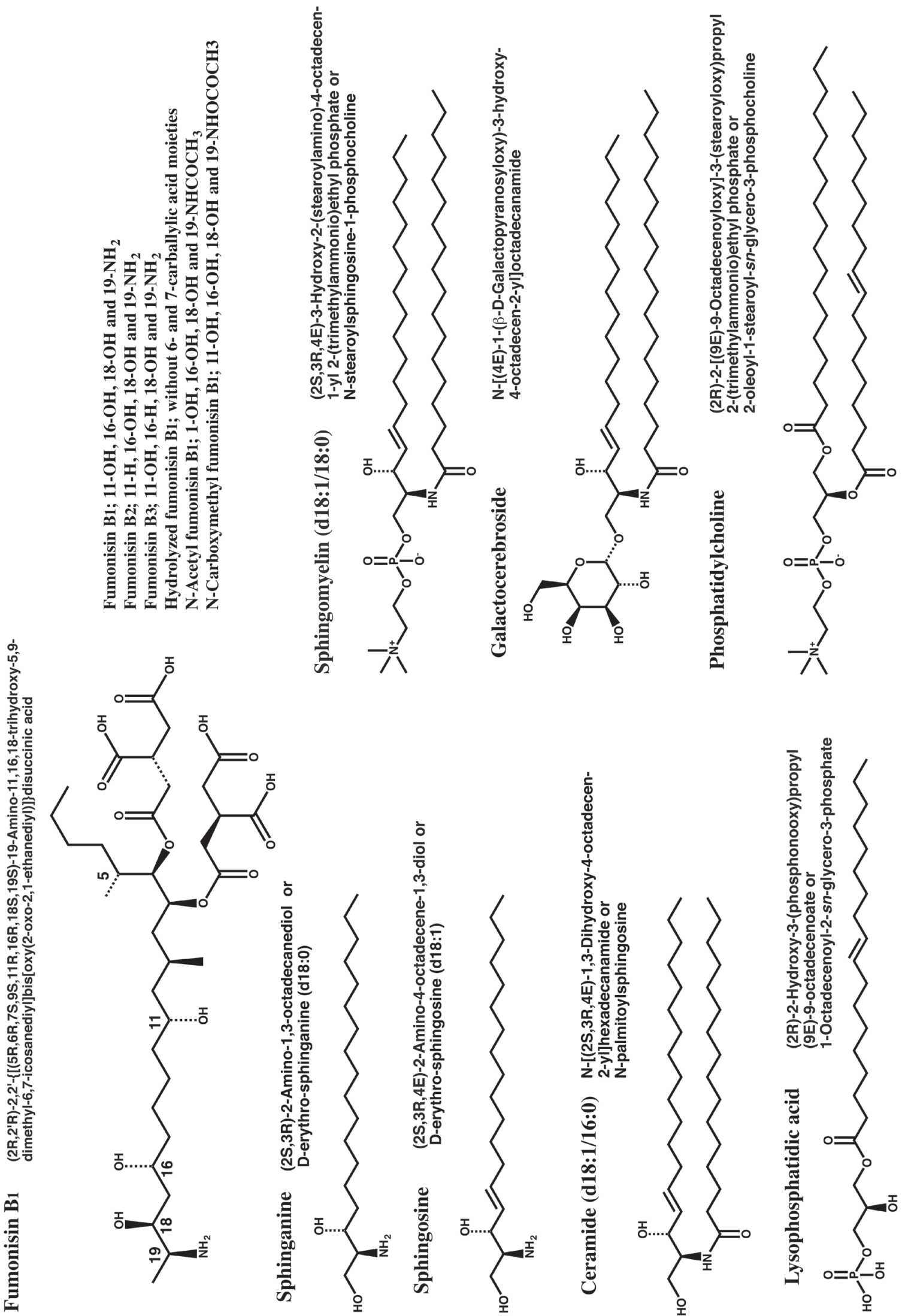

늘 들

.<smiles>CCCCCC(=O)OC(=O)CC(CC(C)=O)C(C)=O</smiles>

旬
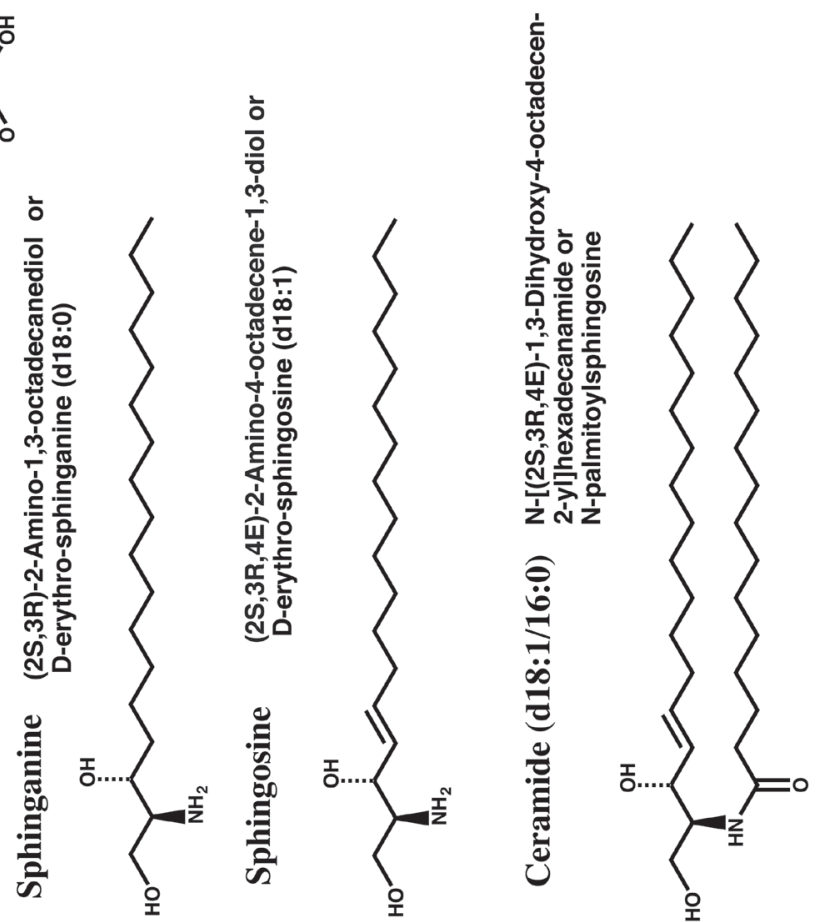

䆛.

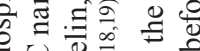

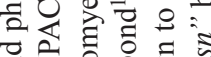
政

递孪 की

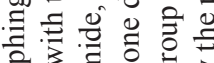

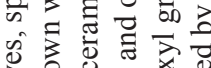

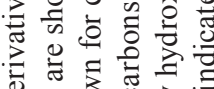

过

然: 
400, 500 and $3000 \mu \mathrm{M}$ for PP5, PP2C $\alpha$, PP2A, PP1 $\gamma 2$ and PP2B, respectively ${ }^{8)}$. FB1 is also reported to interact with arginosuccinate synthase, a urea cycle enzyme ${ }^{9}$.

Wide ranges of food contamination and distinct toxicity targets in different animal species of this toxicant continue to attract attentions of regulatory authorities as well as academic researchers ${ }^{10-12}$. Several reports are available on the toxicity of FB1 and the related chemicals ${ }^{12-16}$. These studies suggested interactions of ceramides/sphingoids on FB1-mediated toxicity. Ceramides, sphingoids ${ }^{17-19)}$ and their metabolites have been discussed as rheostats of cellular signals $^{20-22)}$. In fact, several reports are available on FB1mediated alterations in cellular signals accompanying the changes in ceramide and sphingoid levels ${ }^{23-25)}$. In spite of extensive elaborative researches, causal mechanisms of FB1 toxicity remain obscure in vivo in animal species.

There are couples of unanswered queries on the mechanisms of FB1-mediated toxicity. The major queries include 1) species differences in target organs, 2) sex-related difference in liver and kidney toxicities in rodents, and 3) whether sphingosine is an etiological factor or a surrogate marker. These queries are linked profoundly to a safety assessment of fumonisin intakes from foods. Previous studies on FB1 toxicity mostly dealt with the influence on biological/pharmacodynamic actions of sphingolipids and their metabolites, and poorly focused on the influence on mobilization of individual lipids. Liver is the common target of FB1-mediated toxicity throughout experimental and domestic animals, and cholestatic signs are invariably detected in the exposed animals as described in details below. These data suggested a possible role of hepatic phospholipid supply for the bile excretion on FB1-mediated toxicity. Therefore, the possible mechanism of FB1-mediated toxicity is discussed focusing on the mobilization of phospholipids and sphingolipids in FB1-exposed animals.

*FB1 preparations isolated from cultured materials are used in the biochemical and toxicological studies. The preparation is often noted to contain FB2 and/or other derivatives. Here, FB1 refers to preparations of more than $90 \%$ pure.

\section{Profiles of FB1 pharmacokinetics in Typical Animal Species}

\subsection{Pharmacokinetics in Rats}

Early studies on FB1 using fluorescent derivatization for the detection showed the rapid disappearance from blood circulation and the minimal elimination to urine. Plasma half-life of FB1 quantified as the fluorescent was shown as $3.15 \mathrm{hr}$ after the p.o. administration of $10 \mathrm{mg} / \mathrm{kg}$ b.w. to male Wistar rats, whereas it was calculated $1.03 \mathrm{hr}$ after the i.v. administration of $2 \mathrm{mg} / \mathrm{kg}$ b.w. ${ }^{26)}$. Plasma half-lives were calculated as 1.164 and $1.69 \mathrm{hrs}$ after the subcutaneous injection of FB1 0.8 and $8 \mathrm{mg} / \mathrm{kg}$ b.w., respectively, in new born male Sprague-Dawley (SD) rats ${ }^{27}$. In the oral study, FB1 stayed for longer periods in liver (t1/2, $4.07 \mathrm{hr}$ ) and kidney (t1/2, $7.07 \mathrm{hr}$ ) than in the plasma. Plasma half life of FB1 is reported to be $18 \mathrm{~min}$ after the i.p. administration in male BD IX rats ${ }^{28)}$. Experimental data described above showed the discordance on the disappearance rates of blood FB1 between the oral and parenteral administrations ${ }^{26)}$. Due to the invariability of the elimination kinetics of an identical chemical among different routes of the administration, the terminal portion of the curves observed in the oral experiments is rather likely to represent the absorption rate (in the so-called a flip-flop model). Continued absorption of FB1 is thus expected after the oral administration, although the extent of the absorption is limited in rats.

Studies using 5,9-dimethyl- ${ }^{14} \mathrm{C}$-enriched $\mathrm{FB} 1{ }^{29)}$ confirm the major role of bile excretion and the minimal role of urinary excretion. The biliary excretion recovered in $24 \mathrm{hr}$ shares $67 \%$ of the radioactivity given i.p. to male Wistar rats at a dose of $7.5 \mathrm{mg} / \mathrm{kg}$ b.w. of ${ }^{14} \mathrm{C}-\mathrm{FB} 1^{30}$.

Soon after the intravenous injection of ${ }^{14} \mathrm{C}-\mathrm{FB} 1(4.5 \mu \mathrm{g} /$ head), the blood level dropped rapidly and the levels in liver and kidney exceed the blood level between $0.5 \mathrm{hr}$ and $96 \mathrm{hr}$ after the administration ${ }^{31}$. These data suggest the sequestration of FB1 in tissues including kidney and liver. In addition, a high level of ${ }^{14} \mathrm{C}-\mathrm{FB} 1$ is also continuously detected in the gastrointestinal tract.

The blood level of ${ }^{14} \mathrm{C}$-FB1 was increased rapidly after the intragastric administration $(1 \mathrm{mg} /$ head after addition of unlabeled FB1) and then the low but stable ${ }^{14} \mathrm{C}-\mathrm{FB} 1$ level was maintained until $96 \mathrm{hr}$. In the three consecutive p.o. administrations of ${ }^{14} \mathrm{C}$-FB1 $(1 \mathrm{mg})$, levels of ${ }^{14} \mathrm{C}-\mathrm{FB} 1$ radioactivity in liver and kidney are somewhat higher at $24 \mathrm{hr}$ after the third administration than at the point just after the third administration $^{31)}$. These data suggest the temporal stationary state of ${ }^{14} \mathrm{C}-\mathrm{FB} 1$ in both tissues during the repeated administration.

Cumulative urinary excretion of unchanged FB1 was $2.3,0.8$ and $0.4 \%$, respectively, until four days after gavage administrations of $0.69,6.93$ or $69.3 \mu \mathrm{mol} / \mathrm{kg}$ FB1 (corresponding to $0.5,5$ or $50 \mathrm{mg} / \mathrm{kg}$ b.w.) to male F344 rats. After hydrolysis of the urine, 7.4, 1.2 and $0.5 \%$ of the respective doses were recovered ${ }^{32}$. Thus, no dose-dependent increases were observed in urinary excretion of FB1 in rats.

\subsection{Pharmacokinetics in Pigs}

After an intravenous administration of ${ }^{14} \mathrm{C}-\mathrm{FB} 1(0.4 \mathrm{mg} / \mathrm{kg}$ b.w.), the plasma disappearance rate was calculated $10.5 \mathrm{~min}$ in pigs $^{33)}$. Total $21.2 \%$ and $58.3 \%$ of the radioactivity are 
recovered in urine and feces for three days, respectively. High levels of the radioactivity remain in the kidney and liver among the tissue examined.

Following the intragastric administration of ${ }^{14} \mathrm{C}-\mathrm{FB} 1$ $(0.5 \mathrm{mg} / \mathrm{kg}$ b.w.), the radioactivity appeared in the blood after $30 \mathrm{~min}$ and most was eliminated in the feces (87 to $95 \%$ of the dose) within $72 \mathrm{hr}^{33)}$. Less than $1 \%$ of the dose was excreted in urine. The oral bioavailability was estimated at around $4 \%$ in pigs.

In an oral study using bile duct-cannulated animals, most of the recovered radioactivity was found in the feces (86 to $94 \%$ of the dose) after $72 \mathrm{hr}^{34)}$. Only small amounts of the radioactivity were recovered from the bile (1.7\% of dose) and urine (1.2\% of dose).

Fusarium-cultured materials $26 \mathrm{~g}$ containing $125 \mathrm{mg}$ of FB1 (corresponding to $5 \mathrm{mg} / \mathrm{kg}$ ) was given to male piglets (5 mg/kg b.w.) orally, and plasma FB1 levels are monitored by high-performance liquid-chromatography ${ }^{35)}$. Highest plasma concentration (Cmax) of FB1 appears at $2 \mathrm{hr}$ (Tmax) after the administration. The sharp decline after Tmax suggested the rapid equilibrium with tissue/organ compartment and the half-life ( $t 1 / 2$ of $\beta$-phase) was calculated from the plasma profile as around $12 \mathrm{hr}$. The value is likely to represent the half-life of the absorption in similar to the case with rat pharmacokinetics described above. FB1 was excreted in urine $(0.93 \%)$ and feces $(76.5 \%)$ until $84 \mathrm{hr}$.

Absorption of FB1 was estimated $4 \%$ in pigs fed the $45 \mathrm{mg} / \mathrm{kg}$ diet for 10 days, and the total urinary excretion was $1.5 \%$ using liquid-chromatography mass-spectrometry $(\mathrm{LC} / \mathrm{MS})^{36)}$. Mono-carballylic ester hydrolyzed (24\%) and di-hydrolyzed metabolites (aminopentol, 16\%) were detected together with FB1 (ca 65\%) in the urine. FB1 was detected in liver, kidney, lung and spleen (noted as the decreasing order) even in 10 days after the withdrawal of the FB1-contaminated feed.

After feeding of $100 \mathrm{mg} / \mathrm{kg}$ diet of FB1 for 5 to 11 days, tissue FB1 levels of pigs euthanized or died were determined on serum, bile, lung, liver, kidney, brain, spleen, pancreas, heart, muscle, eye, and fat by $\mathrm{LC} / \mathrm{MS}^{37)}$. High levels of FB1 were detected in kidney, liver, lung, spleen and pancreas.

\subsection{Pharmacokinetics in Velvet Monkey}

Plasma disappearance rate of FB1 was calculated $40 \mathrm{~min}$ after the i.v. administration of $1.6 \mathrm{mg} / \mathrm{kg}$ b.w. in velvet monkey. Significant amounts (5-20\%) were eliminated into the urine, although fecal excretion was the major route of the elimination ${ }^{38)}$. More than $70 \%$ of the radioactivity was recovered within three days after an oral ${ }^{14} \mathrm{C}-\mathrm{FB} 1$ administration $(8 \mathrm{mg} / \mathrm{kg}$ b.w.) in velvet monkeys. Fecal excretion also shared the main route of the elimination. Considerable amounts of radioactivity were detected in the intestines, while the urinary excretion ratios were slightly less in the oral study than in the parenteral study.

\subsection{Urinary Excretion of FB1 in Human}

Daily urine output of volunteers consuming $206 \mathrm{~g} /$ day of tortillas and biscuits prepared from masa and maize flour were determined for FB1 and the derivatives ${ }^{39)}$. Only intact FB1 was detected in urine and the amount was estimated as $0.5 \%$ of the intake. Within five days after the cessation of consumption, urinary FB1 disappeared and thus suggests an apparent half-life of less than $48 \mathrm{hr}$ in humans.

\subsection{Metabolism and Transport}

No enzymatic formation of FB1 metabolite was detected in rat hepatocyte and microsomal systems, suggesting FB1 as a poor substrate of cytochrome $\mathrm{P} 450$ forms ${ }^{40}$ ). Although the urinary excretion of hydrolyzed FB1 without carballylic acid side chain was detected in urine, hydrolysis of ester bonds at C6 or C7 was not observed in hepatocyte system. Thus, no substantial data is available on the enzyme responsible for FB1 hydrolysis.

Experiments with male Mdrla/lb double knockout mice indicate that the cellular or brain transport of FB1 appears to be independent of the P-glycoprotein-mediated transporting system $^{41)}$. Using cell culture systems with or without verapamil or probenecid (P-gp and Mrp inhibitors respectively), involvement of P-gp in the influx/efflux mechanisms of aminopentol (hydrolyzed FB1), but not FB1, was suggested in the intestinal cells ${ }^{42)}$.

To pregnant rats, ${ }^{14} \mathrm{C}$-FB1 $(0.101 \mathrm{mg})$ was given i.v. on gestational day (GD) 15 and the distribution to fetus was examined $1 \mathrm{hr}$ after the injection ${ }^{43)}$. No apparent radioactivity was detected in the fetus. The sphinganine level was also not altered, suggesting the scarce distribution of FB1 in rat fetus. A report, however, noted the presence of radioactive FB1 in both placental and embryonic tissues after the intraperitoneal injection at GD 10.5 to pregnant mouse dams of $\mathrm{LM} / \mathrm{Bc}$ strain, which accompanied the increase in their sphinganine levels ${ }^{44)}$

Although no clear mechanism was available on the selective retention of FB1 in liver and kidney, there are possible contributions of transporters. Interactions of FB1 with organic anion transporter of rat (rOAT1) ${ }^{45}$ ) and of human (hOAT3 $)^{46)}$ were reported in the inhibition study using typical substrates. These data suggest the possibility of efficient uptake in liver and reuptake in kidney of FB1 through OAT family of transporters.

Prolonged retention of ${ }^{14} \mathrm{C}-\mathrm{FB} 1$ radioactivity in intestine and limited excretion in bile of pigs may imply at least partly 
the contribution for intestinal excretion of FB1 through transporters such as ABCG2 (BCRP) known to express in jejunum and liver ${ }^{47,48)}$, although no substantial data is yet available on FB1.

Information on the tissue distribution of FB1 other than liver and kidney is limited in the pharmacokinetic studies described above, but the distributions of FB1 to thymus, adrenal, pancreas are suggested from acute or sub-acute toxicity studies in pigs and other species. These data suggest the sustained absorption at intestines and continued sequestration in susceptible tissues after the oral administration of FB1 in experimental animals.

\section{Profiles of Species- and Sex-related Differences in Toxicity Target Tissues}

\subsection{Toxicity in Mouse}

Liver apoptosis and hepatocellular hypertrophy are detected in female B6C3F1 mice fed $52 \mathrm{mg} / \mathrm{kg}$ diet or more of FB1 (corresponding to $11.5 \mathrm{mg} / \mathrm{kg}$ b.w./day or more) for 28 days ${ }^{10)}$. Pathological changes and altered serum parameters indicative of hepatotoxicity are found in female B6C3F1 mice fed $81 \mathrm{mg} / \mathrm{kg}$ diet (corresponding to $28.9 \mathrm{mg} / \mathrm{kg}$ b.w./ day) of FB1 for 90 days ${ }^{49}$. No apparent changes in clinical parameters are detected in male $\mathrm{B} 6 \mathrm{C} 3 \mathrm{~F} 1$ mice after the $\mathrm{FB} 1$ administration.

In another FB1 feeding study for 28 days $^{50)}$, increases in blood alanine aminotransferase (ALT), alkaline phosphatase (ALP) cholesterol and total bile acids are detected in $\mathrm{B} 6 \mathrm{C} 3 \mathrm{~F} 1$ female mice fed $163 \mathrm{~kg} /$ diet (corresponding to $41 \mathrm{mg} / \mathrm{kg}$ b.w./day) or higher doses of FB1. Bile duct hyperplasia as well as apoptosis is found in female mice fed $234 \mathrm{mg} / \mathrm{kg}$ or $484 \mathrm{mg} / \mathrm{kg}$ diets (corresponding to 62 or $105 \mathrm{mg} / \mathrm{kg}$ b.w./ day). Changes in hepatotoxic parameters such as ALT, ALP, aspartate aminotransferase (AST), cholesterol and total bile acids are also found in male B6C3F1 mice fed FB1 at a high dose (484 mg/kg diet corresponding to $93 \mathrm{mg} / \mathrm{kg}$ b.w./day). These feeding studies are consistently indicative of higher susceptibility of female mice than the males to FB1. Similar differences were observed in mice fed FB1 by the gavage administration for 14 days $^{51)}$. Liver necrosis was detected in female B6C3F1 mice at $15 \mathrm{mg} / \mathrm{kg}$ b.w./day, whereas it was detected in the males at $35 \mathrm{mg} / \mathrm{kg}$ b.w. or higher dose. Both the sexes showed the increases of hepatotoxic parameters such as serum cholesterol and ALT.

Although no obvious damage in kidney was reported in FB1 feeding study, slight increases in the incidence of single epithelial cell necrosis in cortical and medullary renal tubules with vacuolation of the cytoplasm in epithelial cells in the outer medulla, were found in females after the gavage administration at 15 to $75 \mathrm{mg} / \mathrm{kg}$ b.w. of FB1. These effects were not detected in the male mice. In addition, adrenal cortical cell vacuolation was observed at the $15 \mathrm{mg} / \mathrm{kg}$ b.w./ day in the females and at the $35 \mathrm{mg} / \mathrm{kg}$ b.w./day in the males.

Observed higher susceptibilities of female, rather than male, B6C3F1 mice to FB1 in the dysfunctions of kidney and adrenal as well as liver suggest the systemic distribution of a mutual etiological factor.

Female B6C3F1 mice were fed diets containing FB2, FB3, hydrolyzed-FB1, N-acetyl-FB1, or N-carboxymethyl-FB1 (approximately 0, 14, 70, and $140 \mu \mathrm{mol} / \mathrm{kg}$ diet, Fig. 1) for 28 days. None of these diets caused a decrease in body weight gain over the 28 days $^{10)}$.

\subsection{Toxicity in Rat}

Hepatocellular apoptosis was detected in female F344 rats treated with $99 \mathrm{mg} / \mathrm{kg}$ diet of FB1 or the higher doses (corresponding to $12-56 \mathrm{mg} / \mathrm{kg}$ b.w./day) for 28 days ${ }^{52)}$. Bile duct hyperplasia was also detected in the females fed 234 or $484 \mathrm{mg} / \mathrm{kg}$ diets (corresponding to 28 or $56 \mathrm{mg} / \mathrm{kg}$ b.w./day). Hepatocellular apoptosis and bile duct hyperplasia were also observed in the male animals, but at the higher doses, 234 and $484 \mathrm{mg} / \mathrm{kg}$ diets, respectively. Kidney apoptosis was observed in both sexes of the animals treated with $99 \mathrm{mg} / \mathrm{kg}$ diet of FB1 or the higher doses.

In a different feeding study of FB1 for 28 days $^{50)}$, liver apoptosis was detected in female F344 rats treated with the $163 \mathrm{mg} / \mathrm{kg}$ diet (corresponding to $20 \mathrm{mg} / \mathrm{kg}$ b.w./day). Increases of serum cholesterol and total bile acid levels were found after feedings of the $234 \mathrm{mg} / \mathrm{kg}$ diet (corresponding to $28 \mathrm{mg} / \mathrm{kg}$ b.w./day) or the higher dose in the female rats. Liver apoptosis was also observed in the male rats treated with the $234 \mathrm{mg} / \mathrm{kg}$ diet, and increases of serum cholesterol, total bile acid and ALP are detected at the $484 \mathrm{mg} / \mathrm{kg}$ diet (corresponding to $56 \mathrm{mg} / \mathrm{kg}$ b.w./day). Kidney apoptosis was detected in the female at the $163 \mathrm{mg} / \mathrm{kg}$ diet group and in the male at the $99 \mathrm{mg} / \mathrm{kg}$ diet group. Kidney weight loss was found at the $234 \mathrm{mg} / \mathrm{kg}$ diet in both sexes of rats.

Nephrosis involving the outer medulla was found in male F344 rats fed diet containing $9 \mathrm{mg} / \mathrm{kg}$ diet of FB1 (corresponding to $0.21 \mathrm{mg} / \mathrm{kg}$ b.w./day) or the higher dose for 13 weeks, and, to a lesser degree, in the females fed FB1 containing the $81 \mathrm{mg} / \mathrm{kg}$ diet ${ }^{49}$ ). Renal weight decreases were found in both sexes of rats fed at dietary levels of the $9 \mathrm{mg} /$ $\mathrm{kg}$ diet (corresponding to $5.66-6.35 \mathrm{mg} / \mathrm{kg}$ b.w./day) or the higher levels. In this study, hepatotoxicity was not found in rats fed at dietary levels of up to the $81 \mathrm{mg} / \mathrm{kg}$ diet for 90 days.

In a two-year NTP study ${ }^{50)}$, renal tubule apoptosis was observed in male F344 rats fed $15 \mathrm{mg} / \mathrm{kg}$ diet of FB1 (corre- 
sponding to $0.76 \mathrm{mg} / \mathrm{kg}$ b.w./day) from six-week evaluation, and renal tubule epithelial hyperplasia is detected in the groups fed the 50 and $150 \mathrm{mg} / \mathrm{kg}$ diet (corresponding to 2.5 and $7.5 \mathrm{mg} / \mathrm{kg}$ b.w./day) at the final evaluation. No significant increases in the incidence of neoplasms and non-neoplastic lesions were detected in the females fed 5 to $100 \mathrm{mg} / \mathrm{kg}$ diet of FB1.

These diet studies using F344 rats indicate the following points; 1) kidney is the most susceptible target of FB1, 2) liver damages are also occurred at the higher doses, and 3) female F344 rats are rather resistant than the male rats to FB1.

Experiments using both sexes of SD rats also indicate hepatic lesions after the feeding of $150 \mathrm{mg} / \mathrm{kg}$ diet of FB1 (corresponding to 13 or $13.6 \mathrm{mg} / \mathrm{kg}$ b.w./day) for four weeks ${ }^{53)}$. Cortical nephrosis appeared in the males fed $15 \mathrm{mg} / \mathrm{kg}$ diet of FB1 (corresponding to $1.4 \mathrm{mg} / \mathrm{kg}$ b.w./day), and in the females fed the $50 \mathrm{mg} / \mathrm{kg}$ diet $(4.1 \mathrm{mg} / \mathrm{kg}$ b.w./day).

Susceptibility to FB1-mediated nephropathy was also higher in male SD rats than the females in FB1 feeding study ${ }^{43)}$. In a diet study using male SD strain of rats, liver and kidney apoptosis were detected in the groups fed 53 and $6.9 \mathrm{mg} / \mathrm{kg}$ diet of total FBs (corresponding to 5.3 and $0.69 \mathrm{mg} / \mathrm{kg}$ b.w./day), respectively, for three weeks ${ }^{54)}$. Increases in serum ALP and urea nitrogen were also found in male SD rats exposed to $53 \mathrm{mg} / \mathrm{kg}$ diet of total FB. Increases in apoptosis score in liver was detected at the $88.6 \mathrm{mg} / \mathrm{kg}$ diet $(8.86 \mathrm{mg} / \mathrm{kg}$ b.w./day) for 10 days and in kidney at the $13.5 \mathrm{mg} / \mathrm{kg}$ diet (corresponding to $1.35 \mathrm{mg} / \mathrm{kg}$ b.w./day) ${ }^{55}$ ).

Significantly depressed body weight and food consumption were observed in female SD rats treated with gavage administration of FB1 at 35 and $75 \mathrm{mg} / \mathrm{kg}$ b.w./day for 11 days ${ }^{56)}$. Reduced liver weight, elevated serum ALT and histopathological changes suggest hepatic dysfunction at doses of the $15 \mathrm{mg} / \mathrm{kg}$ b.w./day and the higher. Altered renal morphology, together with changes in urine osmolality and urine enzyme levels, was observed at the $5 \mathrm{mg} / \mathrm{kg} / \mathrm{day}$ and the higher doses. In addition, transient increase in cellular vacuolation was detected in bone marrow at a dose of 5mg/ $\mathrm{kg}$ b.w./day. Increased cytoplasmic vacuolation of adrenal cortex cells occurred in rats treated with the $15 \mathrm{mg} / \mathrm{kg}$ b.w./ day. Elevated serum cholesterol was observed at $5 \mathrm{mg} / \mathrm{kg}$ b.w./day of FB1 and the higher.

In male SD rats treated with gavage administration of FB1, glomerular and tubular damages were suggested at $5 \mathrm{mg} / \mathrm{kg}$ b.w./day from the alteration of clinical parameters ${ }^{57)}$. Single cell necrosis is increasingly numerous in the liver from 15-75 mg FB1/kg b.w./day. Thus, clear sex-related difference exists on FB-induced renal apoptosis, but faint in the hepatic apoptosis, in SD rats. Consistent with F344 rats, Female SD rats are more resistant than the males on FB1-induced kidney dysfunctions.

The doses yielding liver and kidney damages are equivalent between the diet study for four weeks and gavage studies for 11 days using both sexes of SD rats. These results among sub-chronic studies are consistent with the view that sustained absorption in intestine of FB1 is a key factor in oral toxicity studies.

Reductions in body weight, food consumption and feces production with polyuria without a compensatory increase in water consumption were observed in male SD rats treated in parenteral (i.p.) with 7.5 or $10 \mathrm{mg} / \mathrm{kg}$ b.w./day for four consecutive days ${ }^{58)}$. In addition to dehydration, decreased absolute organ weights of liver, kidney, spleen and thymus were detected. Elevated levels of serum blood urea nitrogen (BUN) and altered kidney morphology indicate nephrotoxicity. Serum levels of ALP, ALT, AST, cholesterol, total bilirubin, and calcium were elevated, and of glucose and amylase are reduced in these animals. These data suggest the dysfunctions of pancreas as well as kidney and liver.

Damages of lung and intestine, in addition to liver and kidney, are reported in male BDIX rats treated p.o. with $4.7 \mathrm{mg} / \mathrm{kg}$ of $\mathrm{FB1}$ for 12 days and $7 \mathrm{mg} / \mathrm{kg}$ for the successive 9 days of $\mathrm{FB}^{1)}$.

\subsection{Toxicity in Rabbit}

Single or multiple doses of FB1 (less than $0.5 \mathrm{mg} / \mathrm{kg}$ i.v.) caused renal proximal tubular damage in rabbits. Serum levels of urea nitrogen and creatinine were increased and urinary glucose and protein concentrations were also altered ${ }^{59)}$. These findings suggest that FB1 targets the proximal tubular epithelia, especially at the cortico-medullary junction, in rabbit kidney. The increased levels of protein in the urine may be indicative of the extensive tubular epithelial necrosis.

\subsection{Toxicity in Swine}

Swine showed pulmonary edema and hydrothorax after the feeding of fumonisin-contaminated corn ${ }^{60)}$ or intravenous injection of FB1 ( 0.174 to $0.4 \mathrm{mg} / \mathrm{kg}$ b.w.) daily for 4 to 7 days ${ }^{61)}$. Pancreatic lesions were present in all pigs developed pulmonary edema/hydrothorax. Liver changes were observed in all pigs fed FB1 diet for the feeding study ${ }^{61)}$. The animal shows typical lesions including interlobular edema of lung and pancreatic lesions ${ }^{62)}$.

Feeding of $20 \mathrm{mg} \mathrm{FB1} / \mathrm{kg}$ b.w./day for four days resulted in the pulmonary edema and hepatotoxicity in pigs ${ }^{63)}$. Pigs developed pulmonary edema beginning on day 3 ; none survived beyond day 4. Progressive elevations in hepatic parameters, including serum enzymes, bile acids, total bilirubin, and histologic changes, began on day 2. Early histological 
changes in the lung consisted of perivascular edema followed by interlobular and peribronchial edema without the sign of inflammation. Ultrastructurally, alveolar endothelial cells contained unique accumulations of membranous material within pulmonary intravascular macrophages beginning on day 2. Marked elevations in sphinganine, sphingosine, and their ratio (sphinganine/sphingosine $\mathrm{Sa} / \mathrm{So}$ ) began on day 1 for all tissues, irrespective of being morphologically (lung, liver) or not (kidney, pancreas) ${ }^{63)}$. Thus, FB induces early elevations in sphingolipids and hepatic damage, followed by alveolar endothelial damage in pigs ${ }^{63,64)}$. In an experiment using pulmonary endothelial cells, increased albumin permeability was observed in the presence of 30 to $50 \mathrm{mM} \mathrm{FB1}{ }^{65)}$. Neither toxicity nor ultrastructural changes were, however, detected after the exposure at 5-20 $\mu \mathrm{g} / \mathrm{ml}$ (corresponding to 7-28 $\mu \mathrm{M}$ ), relevant to in vivo exposure levels, for seven days ${ }^{65)}$. These data may favor the idea that pulmonary dysfunction is an indirect consequence of the damage on primary target tissue(s).

\subsection{Toxicity in Horse}

Leukoencephalomalacia is a typical toxicity of FB1 in horses ${ }^{66,67)}$. Gavage administration of cultured materials containing FB1 (2.5 g cultured material $/ \mathrm{kg}$ b.w./day for seven days) to a horse caused severe hepatotoxicity and mild edema of the brain ${ }^{68)}$. In a similar experiment with the cultured material of $1.25 \mathrm{~g} / \mathrm{kg}$ b.w./day, another horse developed mild hepatic disorder and moderate edema of the brain. In both animals the brain edema was particularly noticeable in the medulla oblongata.

A horse given intravenously 7 times from day 0 to day 9 with $0.125 \mathrm{mg}$ of $\mathrm{FB1} / \mathrm{kg}$ b.w./day showed clinical signs of neurotoxicity, which appeared on day 8. Euthanasia was performed on the horse on day 10 while the animal was in a tetanic convulsion. The principal lesions were severe edema of the brain and early, bilaterally symmetrical, focal necrosis in the medulla oblongata ${ }^{68)}$.

In horses treated intravenously with $0.05-0.20 \mathrm{mg} / \mathrm{kg}$ of FB1 for up to 28 days, hindlimb ataxia, delayed forelimb placing, and decreased tone and movement of tongue are observed $^{69)}$. These results indicate that FB1 induced dosedependent changes in the cerebrospinal fluid and nerve system.

\subsection{Developmental Toxicity}

Pregnant CD1 mice were treated orally with semi-purified extracts of $F$. moniliforme containing $\mathrm{FB} 1$ at a dose of 0 , $12.5,25,50$ or $100 \mathrm{mg} / \mathrm{kg}$ b.w./day between GD 7 and 15 . At GD 18, litters were examined for gross abnormalities and for skeletal or visceral examinations ${ }^{70)}$. Significant maternal mortality was observed in mice treated with the 50 and $100 \mathrm{mg} / \mathrm{kg}$ b.w./day. Maternal body weight gains, live-offspring number per litter, and mean body weight of the offspring were decreased at FB1 doses of $25 \mathrm{mg} / \mathrm{kg}$ b.w./ day or the higher. The frequency of resorption of implants increased at all the doses in a dose-dependent manner. The incidence of ossification deficits also increased from the $25 \mathrm{mg} / \mathrm{kg}$ b.w./day dose. Cleft palate was observed at the highest FB1 dose group. Maternal intoxication manifested as ascites associated mainly with increased histopathological scores reflecting hepatocellular damage. Concomitant increases in serum ALT on GD 12 was also observed at all doses above $12.5 \mathrm{mg} / \mathrm{kg}$ b.w./day of FB1. Authors ${ }^{70)}$ suggest based on these results that FB1 is developmentally toxic in mice, and that this toxicity may be mediated by maternal hepatotoxicity.

In addition, extracts from Fusarium cultures and purified FB1 have been shown to be embryotoxic to hamsters ${ }^{71,72)}$,

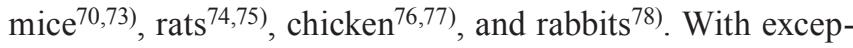
tion of studies with hamsters and chicken, embryo toxicities in vivo appeared in association with signs of maternal toxicity $^{73-75,78)}$.

FB1 was toxic, especially to pre-somite stage, in a whole embryo system of rat. Embryo growth were retarded, and the development was inhibited without specific abnormalities. Addition of ceramide, $\mathrm{N}$-acetylsphingosine or raft ganglioside Gm1 did not reverse FB1-mediated toxicity, suggesting that inhibition of sphingolipid synthesis was not the cause of the toxicity. Further, the main metabolite of FB1, aminopental (AP-1), inhibited embryonic growth, but was 100-fold less toxic than $\mathrm{FB}^{79)}$.

Due to the possible association of FB1-contaminated foods with an outbreak of neural tube defects (NTD) occurred in 1991 in south Texas county bordering Mexico ${ }^{80,81)}$, attentions were focused on risks of FB1 exposure to NTD.

Both in vitro ${ }^{82)}$ and in vivo studies treated FB1 parenterally $^{44)}$ showed the association of FB1 exposure with NTD in mice.

\section{Currently Known Biochemical Alterations in FB1-exposed Animals}

Considerable amounts of data have been accumulated for the biochemical changes in FB1-mediated toxicities. These may be summarized and subdivided into bile acids, sphingolipids and phospholipids from the point of endobiotics involved. 


\subsection{Overflow of Bile Acids in Systemic Circulation}

As described above, liver is the common target of FB1mediated toxicity throughout the experimental and domestic animals examined, and cholestatic signs, including increased levels of serum bile acid, are consistently detected in the exposed animals.

The predominant bile acids in control mouse liver are reported to be taurocholic acid $(86.1 \pm 18.5 \mathrm{nmol} / \mathrm{g}$ liver $)$ and cholic acid (4.7 \pm 0.9$)$, tauro- $\beta$-muricholic acid (34.2 \pm 8.8$)$ and $\beta$-muricholic acid $(35.1 \pm 5.0)$, and tauro- $\omega$-muricholic acid $(18.1 \pm 4.5)$ and $\omega$-muricholic acid $\left.(11.8 \pm 2.1)^{83}\right)$. These are excreted in bile, but in situations of the restricted bile excretion, bile acids are excreted in urine through kidney. The hepatic levels of major bile sulfates, taurocholic acid 7-sulfate, cholic acid 7-sulfate, and taurochenodeoxycholic acid 7-sulfate were higher in male mice than in female mice ${ }^{83)}$. This indicates the male-dominant sulfation of cholic acid and chenodeoxycholic acid, and thus in turn suggests that hepatic elimination of hydrophobic bile acids is delayed in female mice. The observed sex-related difference in bile acid excretion is consistent with higher susceptibility of female mice to FB1.

Bile acid exists within enterohepatic circulation ( $>96 \%)$, and clearance through the plasma-renal system occurs selectively at the over-limiting capacity of liver to send bile acids into bile as described above. Obstruction of the common bile duct leads to cholestatic liver. Cholestasis results in the accumulation of hydrophobic bile acids in liver. As a possible cause of liver injury, direct action of bile acids has been proposed from apoptosis of hepatocyte cell line ${ }^{84)}$, which is prevented by a pan-caspase inhibitor, z-VAD-FMK ${ }^{85)}$.

Unlike in mice, urinary excretion of taurocholate is higher in female rats than in male rats due to the higher renal expression of a specific Oatp1 transporter ${ }^{86)}$. An activity of MRP3 transporter mediating bile acid effluence to plasma is higher in female rats than the males ${ }^{87-89)}$. Further, hepatic sulfating activity of bile acids, which is mediated by hydroxysteroid sulfotransferase, is higher in female rats than the males ${ }^{90,91)}$. These sex-related differences on bile acids are accorded with the higher susceptibility of kidney of male rats to FB1.

Thus, data on plasma bile acids are in good agreement with the idea of bile acid-involvement on FB1-mediated kidney toxicity. No morphological changes with apoptosis or activation of caspases are, however, evident in vivo in bile duct ligated rats and mice ${ }^{92-94)}$. In addition, serum pro-apoptotic bile acid levels are approximately 1,000-fold less than needed to stimulate apoptosis in vitro ${ }^{95)}$. Instead, neutrophil-induced liver injury was proposed in bile-duct ligated animals ${ }^{96,97)}$ Another study also implies that a hydrophobic lithocholic

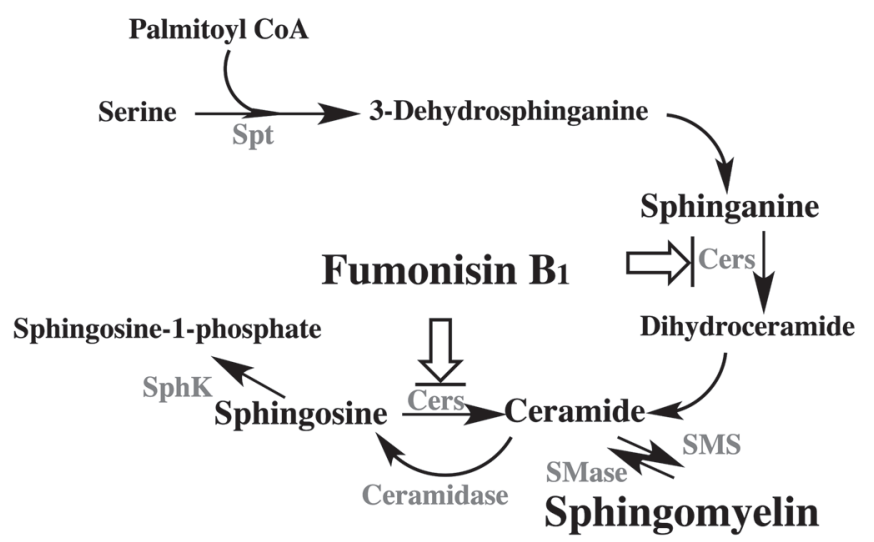

Fig. 2. Biosynthesis of sphingomyelin and interaction of fumonisin B1

Interaction points of fumonisin B1 are shown as arrows with bar. Enzymes are shown in gray color. CerS; ceramide synthase (sphinganine/sphingosine $\mathrm{N}$-acyltransferase), SMS; sphingomyelin synthase, SMase; sphingomyelinase, SphK; sphingosine kinase, and Spt; serine palmitoyltransferase.

acid leads to cholestasis through the disruption of phospholipid and sphingolipid homeostasis in mice ${ }^{98)}$.

Certain amounts of bile acids are also excreted in urine of pig. Hydrophilic $\gamma$-muricholic acid, but not cholic acid, is excreted in urine and bile in this species ${ }^{99,100)}$.

Therefore, the role of bile acid effluence into systemic circulation for FB1-mediated kidney toxicities is yet unclear, although the chronic exposure to bile acids is possible to exacerbate functions of liver in mice and kidney in rats.

\subsection{Alteration of Sphingoid and Ceramide Levels}

FB1 is known to influence several distinct signaling pathways of sphingoids including ceramide synthesis, sphingosine-1-phosphate receptor and glycosylphosphatidylinositol anchoring ${ }^{19,101-103)}$.

\subsubsection{Sphingoid}

FB1 inhibits ceramide synthase, a key enzyme in the de novo biosynthesis of sphingolipids (Fig. 2). The increase of free sphinganine (and also the ratio with sphingosine) in tissue after the administration of FB1 is used as a biomarker for fumonisin exposure. A single subcutaneous injection of FB1 caused an increase in free sphingoid bases in male BALB/c mice. A significant time-dependent increase in sphingoid bases occurred in the intestine and liver peaking at 4-8 hr and declining to control levels by $24 \mathrm{hr}$. The level of free sphinganine remained high in the kidney ${ }^{104)}$. This persistence in renal cells was rapidly reversed in the presence of the inhibitor (ISP-1/myriocin) ${ }^{105}$ ) of serine palmitoyltransferase, which catalyzes sphinganine biosynthesis. 
The associations of sphingoid levels with FB1 toxicities were also detected in kidney and liver of rats ${ }^{55)}$ and in lung of pigs ${ }^{63)}$. However, no clear mechanistic clues have been provided between FB1-mediated changes in sphinganine levels and organ toxicities in vivo in these animal species.

Calmodulins (CaM1-4) are small, ubiquitous adaptor proteins that amplify calcium cation's diminutive size to the scale of proteins ${ }^{106)}$. Sphingosine is a potent inhibitor of several calmodulin-dependent enzymes including multifunctional $\mathrm{Ca}^{2+} /$ calmodulin-dependent protein kinase, $\mathrm{Ca}^{2+} /$ calmodulin-dependent phosphodiesterase, and smooth muscle myosin light chain kinase ${ }^{107)}$. Inhibition of each of the enzymes is competitive with calmodulin, suggesting that sphingosine may be a calmodulin antagonist.

The activity of acidic sphingomyelinase was enhanced and liver sphingomyelin content was decreased following five daily treatments with FB1 in mice. The expression and activities of serine palmitoyltransferase and sphingosine kinase were increased significantly in liver following FB1 treatment. These data suggest that FB1-mediated inhibition of ceramide synthase stimulates sphingolipid-metabolizing systems to maintain a balance of cellular sphingolipids ${ }^{23)}$.

\subsubsection{Ceramide and ceramide synthase}

Ceramide is a lipid-signaling molecule that plays critical roles in regulating cell behavior ${ }^{108)}$. Six distinct forms of mammalian ceramide synthases (CerS) mediate syntheses of ceramides with restricted acyl chain lengths ${ }^{109-111)}$. CerS1, CerS2, CerS3, CerS4 and CerS5/6 mediate mainly the formation of $\mathrm{C} 18, \mathrm{C} 22, \mathrm{C} 26, \mathrm{C} 18$ and $\mathrm{C} 16$ dihydroceramides, respectively ${ }^{112)}$.

The sphingolipid contents of lung and liver were compared in normal and FB1-exposed piglets (gavaged with $1.5 \mathrm{mg}$ FB1/kg b.w. daily for 9 days $)^{14)}$. The effect of the toxin on each CerS form was deduced from an analysis of its effects on individual ceramide and sphingomyelin species. As expected, the total ceramide content decreased by half in the lungs of FB1-exposed piglets, Total ceramide increased 3.5fold in the livers of FB1-exposed animals, possibly due to the degradation of sphingomyelin. These data are consistent with the view that FB1 is more prone to bind to CerS4 and CerS2 to deplete lung d18:1/C20:0 and d18:1/C22:0 ceramides $^{113)}$. These views are consistent with the idea that differences in CerS4, CerS2, and CerS1 expressions in targets are involved in the toxicity of FB1.

CerS2-deficient mice, carrying an insertion (gene trap) in the CerS2 gene to generate transgenic mice that lack CerS2 mRNA, lacked ceramide synthase activity toward C24:1 in the brain as well as the liver, and showed only very low activity toward C18:0-C22:0 in liver and also reduced activ- ity toward $\mathrm{C} 22: 0$ residues in the brain ${ }^{114)}$. These mice also exhibit strongly reduced levels of ceramide components with very long fatty acid residues ( $>$ or $=\mathrm{C} 22$ ) in the liver, kidney and brain. In addition, histochemical staining of myelin is progressively lost from the early adulthood, followed by about $50 \%$ loss of compacted myelin and $80 \%$ loss of myelin basic protein. Starting around 9 months, both the medullary tree and the internal granular layer of the cerebellum showed significant signs of degeneration associated with the formation of microcysts. Beyond seven months, the CerS2-deficient mice developed hepatocarcinomas with local destruction of tissue architecture and discrete gaps in renal parenchyma.

In another CerS2-deficient mouse model ${ }^{115)}$, liver ceramide and downstream sphingolipids were devoid of very long (C22-C24) acyl chains, consistent with the substrate specificity of CerS2 toward acyl-CoAs. Unexpectedly C16-ceramide levels were elevated in vivo, although C16-ceramide synthesis in vitro was not increased. Levels of sphinganine were also significantly elevated, by up to 50 -fold in the liver.

With the exceptions of glucosylceramide synthase and neutral sphingomyelinase 2, none of the other enzymes tested in either the sphingolipid biosynthetic or metabolic pathways were significantly changed in the liver. Total glycerophospholipid and cholesterol levels were unaltered, although there was a marked elevation in C18:1 and C18:2 fatty acids in phosphatidylethanolamine (PE), concomitant with a reduction in C18:0 and C20:4 fatty acids. These results indicate that CerS2 activity supports different biological functions: maintenance of myelin, stabilization of the cerebellar as well as renal histological architecture, and protection against hepatocarcinomas possibly through crosstalk and regulation between the various branches of lipid metabolic pathways ${ }^{115)}$. These data are consistent with the association of ceramides and sphingomyelin on FB1-mediated liver and brain toxicities.

\subsubsection{Sphingolipid signals}

On the interaction of sphingolipids with cellular signal molecules, hypoxia-reoxygenation of rat renal tubular epithelial NRK-52E cells resulted in a significant increase in ceramide synthase activity without any significant change in acid or neutral sphingomyelinase. The hypoxia-reoxygenation of NRK-52E cells was also associated with the release of endonuclease $\mathrm{G}$ from the mitochondria to the cytoplasm. It further led to the fragmentation of DNA and cell death. Addition of $50 \mu \mathrm{M}$ FB1 suppressed hypoxia-reoxygenationinduced ceramide generation and provided protection against the release of hypoxia-reoxygenation-induced endonuclease G, DNA fragmentation, and cell death ${ }^{116)}$. FB1 has also been shown to inhibit various inducer mediated-cell deaths in cell 


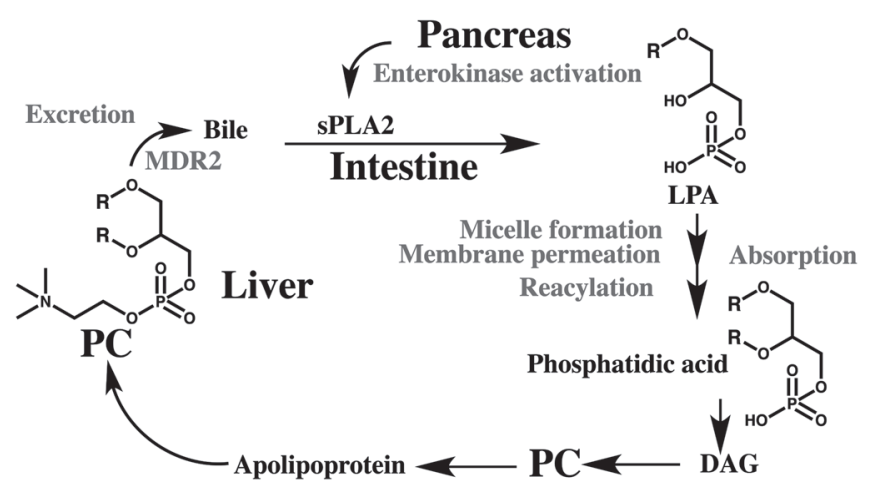

Fig. 3. Enterohepatic circulation of phosphatidylcholine R; fatty acids, DAG; diacylglycerol, LPA; lysophosphatidic acid, MDR2; ABCB4 phosphatidylcholine transporter, PC; phosphatidylcholine, sPLA2; secretory phospholipase A2 (IB form). Specific process and enzymes are shown in gray color.

lines ${ }^{110)}$.

In contrast, sphingolipid metabolites such as ceramide, glycosphingolipids, sphingosine 1-phosphate and gangliosides are involved in $\beta$-cell signaling pathways and processes implicated in $\beta$-cell diabetic disease such as apoptosis, $\beta$-cell cytokine secretion, endoplasmic reticulum-to-Golgi vesicular trafficking, islet autoimmunity and insulin gene expression $^{117)}$. Further, FB1-mediated activation of NF- $\mathrm{kB}$ (nuclear factor-kappa B) and the sequential induction of $\mathrm{TNF} \alpha$ (tumor necrosis factor $\alpha$ ) expression stimulated in the subsequent increase in caspase 3 activity in porcine renal proximal cell-derived LLC-PK1 ${ }^{118)}$. Thus influences of sphingoids on cellular signal molecules may depend on the cell type and experimental conditions to exert the protecting or exacerbating effects. The role of signal molecules derived from sphingoids remain obscure in vivo on FB1-mediated toxicity ${ }^{119)}$.

\subsection{Supply Circle of Phospholipid}

\subsubsection{Supply through the intestinal absorption}

Similar to xenobiotics, various endobiotics are excreted through bile. Non-esterified cholesterol, bile acids, phosphatidylcholine (PC) and glutathione are the main components of bile. Specific transporters expressed in canalicular membrane are involved in their transfers from liver to bile duct (Fig. 3). ATP-binding cassette transporters, ABCG5/8, ABCB10 (BSEP), ABCB4 (MDR2) and $\mathrm{ABCC} 2$ (MRP2), mediate the transfer of cholesterol, cholates, $\mathrm{PC}$ and glutathione in livers, respectively. Cholesterol, bile acids and PC are forming micelles, holding certain ranges of their ratios in the bile after the membrane permeation to maintain the bile fluidity ${ }^{120,121)}$, and descend to gall bladder and intestine. Insufficient supply of PC, thus, affects the excretion of cholesterol and bile acids. Bile flow is driven mainly by the levels of bile acids ${ }^{122)}$ and glutathione ${ }^{123)}$ and the deficient supply of $\mathrm{PC}$ is able to reduce the rate of bile flow. Prolonged irregular ratios of bile components would thus promote formation of cholestatic conditions.

Dysfunctions in canalicular components are known to associate with enhanced levels of ALP and bilirubin in the body. Observed changes in biochemical parameters, excesses of cholesterol and bile acids compared to triglycerides in FB1-treated mice and rats are consistent with the notion of shortage of phospholipids, particularly PC, to excrete in bile. Liver PC is maintained by supplies from two sources ${ }^{124)}$. One is a conversion from triglycerides within hepatocytes. The other is intestinal absorption of phospholipids from bile and diet. Bile supplies the majority (up to $90 \%$ ) of intestinal phospholipids. Intestinal phospholipids are hydrolyzed to lysophosphatidic acid (LPA) in the presence of secretory phospholipase A2 (sPLA2) released from the pancreas. LPA forms micelles with monoacylglycerol, fatty acids, bile acids and cholesterol, and then passes through the brush border membrane. Within enterocytes, LPA is acylated to phosphatidic acid and then to PC and PE. These phospholipids are delivered as particles like chylomicron and apolipoprotein B to tissues.

\subsubsection{Supply through the liver synthesis}

Phospholipids are biosynthesized from diacylglycerols in tissues like liver. Liver has two routes of PC biosynthesis. The main route is a sequential pathway starting from choline to phosphocholine to CDP choline and then to PC. Another route is three-consecutive methylations of PE to form PC. Methionine is the donor of the methyl group. The latter route is found only in liver.

CTP:phosphocholine cytidylyltransferase $\alpha(\mathrm{CCT} \alpha)$ is essential for production of PC of animal cell membranes and is proteolytically sensitive ${ }^{125)}$. Calmodulin stabilized $\mathrm{CCT} \alpha$ from the calpain-mediated proteolysis. Mapping and site-directed mutagenesis of CCT $\alpha$ uncovered a motif (LQERVDKVK) harboring a vital recognition site, Gln(243), whereby calmodulin directly binds to the enzyme. Thus, calmodulin, through antagonizing calpain, serves as a novel binding partner for CCT $\alpha$ that stabilizes the enzyme under proinflammatory stress ${ }^{126}$ ). The CDP-choline pathway contributes PC supply for bile secretion. The function of CCT $\alpha$ may be impaired in the presence of an antagonist of calmodulin, sphingosine as described in the section of 4.2.1 (Sphingoid), and also through the direct interaction of CCT $\alpha$ with sphingosine ${ }^{127}$, and indirectly through the repression of CCT gene transcription ${ }^{128)}$. Gene knockout of either CCTa (Pcytla) or PE N-methyltransferase (Pemt), however, had no strike effect on bile secretion or composition, suggesting 
the existence of effective metabolic compensation mechanism $^{129,130)}$.

PC synthesis is reduced in the liver of Pemt-null mice. Thus, treatment of Pemt null mice with choline-deficient diets results in abrupt death (within five days) ${ }^{131}$ ). Double knockout mice of Pemt and Abcb4 (Mdr2) are somewhat resistant to choline-deficient diets ${ }^{132}$, through knockout of the PC-transporter Abcb4 (Mdr2) to relieve PC loss. The $\operatorname{Mdr} 2(-/-) / \operatorname{Pemt}(-/-)$ mice also adapt to severe choline deprivation through several mechanisms, including choline recycling by induction of PLA2, by the activity of choline kinase, and CCT $\alpha$ activities and also by a strikingly decreased expression of choline oxidase ${ }^{132)}$. These pathological models raise a possibility of uncompensated loss of PC in bile as a main etiological factor in FB1-treated animals, in addition to FB1-mediated inhibition of ceramide synthase ${ }^{102,133)}$.

\subsection{Possible Trigger Point of PC-supply Dysfunction \\ 4.4.1 Lipase function}

PC is produced from diacylglycerol and CDP-choline. Decreased supply of triacylgycerol from intestine may affect the PC supply in liver. Orlistat is a potent, specific and irreversible inhibitor of gastric and pancreatic lipases ${ }^{134}$. This drug forms a covalent bond with the active serine of both lipases in the lumen of the gastrointestinal tract, which prevents the hydrolysis of dietary fat into absorbable monoacylglycerol. In patients taking orlistat, levels of both cholesterol and LDL are markedly reduced ${ }^{135)}$. However, orlistat does not severely affect the plasma triacylglycerol level. The reduction of plasma cholesterol level observed are rather inconsistent with the no clear changes in FB1-mediated animals. These data are rather discordant with the idea that secreted-lipase dysfunction is a main causal mechanism of FB1-mediated liver toxicity.

\subsubsection{Pancreatic phospholipase function}

Levels of total cholesterol in sera and livers were significantly increased in the rats fed FB1 $(250 \mathrm{mg} / \mathrm{kg}$ diet $)$ for 21 days, while the liver sphingomyelin and PE were significantly decreased and increased, respectively. In a long-term study, only PE was significantly increased in all the FB1-treated animals ${ }^{136}$. In mice treated with FB1 for more than one week, changes in biochemical parameters become apparent. Increases in plasma values of ALT, ALP, bilirubin, cholesterol and bile acids are detected. FB1 also caused significant cholestasis and liver necrosis in pigs ${ }^{62)}$. These data suggest the commonality of hepato-biliary dysfunction, particularly cholestasis, in FB1-treated animals.

As described in the section of 4.3.2 (Supply through liver synthesis), insufficient supply of PC in bile secretion is likely to participate in the FB1-mediated cholestasis. Enhanced synthesis of PC through the CDP-choline pathway and from $\mathrm{PE}$ and methionine is necessary to compensate the loss of $\mathrm{PC}$ in the bile.

Studies with an experimental animal model have shown that choline and methionine deficiency causes dysfunctions of liver and pancreas ${ }^{137,138)}$. Young female CD1 mice fed a choline-deficient, ethionine-supplemented (CDE) diet for $24 \mathrm{hr}$ develop hemorrhagic pancreatic necrosis with a 5-day mortality rate of approximately $50 \%{ }^{139)}$. At the end of the diet administration, the in vivo discharge of digestive enzymes is blocked, disappearance of exocytosis took place, and zymogen granules accumulate within acinar cells. Thus, the CDE diet does not affect the general phenomenon of membrane fusion-fission but specifically inhibits the membrane fusionfission associated with exocytosis. Twenty-four hours after withdrawal of the CDE diet, discharge of zymogen granules into lysosomes (crinophagy) can be observed, and, $24 \mathrm{hr}$ later, autophagocytosis is noted.

In fact, FB1-mediated pancreatic dysfunction is observed in rats ${ }^{58)}$ and pigs ${ }^{60,64)}$. The pancreatic disorders may be associated with methionine deficiency as discussed in later.

Young female mice, fed a diet deficient in choline and supplemented with ethionine, develop acute necrotizing hemorrhagic pancreatitis, and the incidence is greater in young and female mice than in adult and male mice ${ }^{140,141)}$. In contrast, female rats are less susceptible than the males to the acute effects of choline deficiency, such as fatty liver and impaired secretion of triglycerides into the blood plasma ${ }^{142)}$. In addition, protection conferred by ethinylestradiol in the livers of rats fed a methionine- and choline-deficient diet is consistent with the relative insensitivity of female rats to the hepatotoxicity of dietary methyl donor insufficiency ${ }^{143)}$. Observed sex-related differences in CDE diet-mediated liver toxicity are consistent with those in FB1-mediated liver toxicities in mice and rats. These data suggest the possible association of hepato-pancreatic changes on FB1-mediated toxicity.

For pancreatic zymogens, two steps of their activations are required with the exception of trypsinogen. In the first stage, active trypsin is generated from its zymogen by enterokinase, and in the second stage trypsin activates the remaining zymogens giving rise to the well-known activation cascade of pancreatic enzymes ${ }^{144)}$. Enterokinase is synthesized in the enterocytes of the proximal small intestine ${ }^{145}$.

DL-Ethionine has a destructive effect on the acinar tissue of the pancreas of rats ${ }^{137)}$. The destructive effects of ethionine on liver and pancreas can be completely prevented by the simultaneous administration of equal molar amounts 
of methionine. Ethionine affects protein synthesis through inhibiting the incorporation of methionine and glycine into proteins in the liver ${ }^{146)}$.

As described above, treatment of Pemt-null mice with choline-deficient diets results in severe liver dysfunction and abrupt death within five days. PC deficiency is replenished by a synthesis from PE in livers in the presence of Pemt. Methionine is utilized for the methyl donor.

In a state of reduced supply of zymogen from pancreas, decreased digestion capacity of protein at intestine results in the diminished amounts of methionine availability. Methionine supplied through portal vein is consumed extensively within liver for the PC and protein syntheses ${ }^{147)}$. These situations would link to methionine-deficient conditions in other tissues. Methionine deficiency in the pancreas may promote dysfunctions of pancreas in similar to those in rodents treated with $\mathrm{CDE}$ diet. Consistent with this idea, FB1 treatment resulted in the up-regulation of the intestinal brush border transporter B0AT and the basolateral transporter $y+$ LAT1 in newborn chickens, suggesting the demand of an increased intracellular uptake of neutral amino acids such as methionine ${ }^{148)}$.

In fetal rat pancreas cells, methionine is required for the growth of the exocrine pancreas, and the higher levels are required to achieve basal or maximal differentiation of acinar cells ${ }^{149)}$. The basal requirement was determined to be $30 \mathrm{mg} / \mathrm{L}$ methionine, and a level of $80 \mathrm{mg} / \mathrm{L}$ supported maximal differentiation.

\subsubsection{Secretory phospholipase}

Secretory phospholipase A2s (sPLA2s) are small secreted proteins $(14-18 \mathrm{kDa})$, proteolytically activated after their release from the pancreas. sPLA2s require submillimolar levels of $\mathrm{Ca}^{2+}$ to liberate LPA. An sPLA2-deficient mutant showed no clear alteration of phospholipid absorption possibly by the feedback regulation of secretins and partly as a result of compensation by other PLA2 forms ${ }^{150)}$. Pancreatic PLA2 also has intrinsic secretin-releasing activity ${ }^{151,152)}$. Secretin regulates exocrine secretion as well as gastric motility. A pancreas injured by FB1 may not function well to compensate the secretion. In addition, FB1 is a chelating agent of divalent cations like calcium ion. Considerable retention of FB1 in intestinal cells is expected from the increase of sphingoids even after the s.c. administration in mice ${ }^{104)}$, suggesting the possible contact of the FB1 with secretory phospholipase A2. These situations would exacerbate the absorption capability for phospholipids at intestine.

In addition to its enzymatic function, sPLA2 can exert various biological responses through the binding to specific M-receptors. Physiologically, sPLA2s play important roles on the neurotransmission in the central nervous system and the neuritogenesis in the peripheral nervous system. sPLA2 are implicated to link to the neurodegenerative diseases like Alzheimer's disease and cerebrovascular diseases like stroke ${ }^{153)}$. Release of sPLA 2 in the circulation during pancreatic dysfunction may evoke the signal through M-receptor.

M-type phospholipase A2 receptor (PLA2R) is expressed in podocytes in human glomeruli. One of the ligands, group IB secretory phospholipase A2 (sPLA2 IB), is expressed higher in chronic renal failure patients than in controls. After binding to human podocyte PLA2R in vitro, sPLA2 IB form induced podocyte apoptosis in a time- and concentrationdependent manner ${ }^{154)}$. sPLA2 IB upregulated PLA2R and increased ERK1/2 and cPLA2 $\alpha$ phosphorylation in podocytes, which resulted in enhanced apoptosis. In contrast, PLA2Rsilenced human podocytes displayed attenuated apoptosis. These data indicate that sPLA2 IB has the potential to induce human podocyte apoptosis via binding to the PLA2R. No PLA2R1 is expressed in mouse kidney podocytes ${ }^{155)}$ and thus the role of SPLA2 on FB1-mediated kidney toxicity in mice remains unclear.

\subsubsection{Intestinal membrane alteration and zinc- deficiency}

Feeding FB-containing diet (FB1 + FB2 $25.4 \mathrm{mg} / \mathrm{kg}$ feed) for 15 days to chickens resulted in altered glycosylation of mucin and in a decreased level of mucin 2 mRNA in the duodenum $^{148)}$. In addition, specific mRNA level of basolateral zinc transporter ( $\mathrm{ZnT} 1)$ was reduced in jejunum of FB-treated chickens ${ }^{148)}$, which may contribute to maintain the zinc ion in brush border.

Marginal zinc-deficiency is known to associate with the decreased absorption of triglyceride in rats ${ }^{156)}$. Plural mechanisms including apolipoprotein B mRNA editing ${ }^{157)}$ are known to participate in this phenomenon. FB1 includes two moles of carballylic acid in the molecule, which are chelating agents of divalent cations ${ }^{158)}$. FB1 is thus possible to contribute intestinal zinc deficiency as a zinc-chelating agent. The primary defect in lipid absorptive processes in zinc-deficient rats occurred in the formation of chylomicrons ${ }^{159)}$.

\section{Interaction of Phospholipids in Tissue Membranes}

\subsection{Lipid Raft Anchoring and Folate}

Glycosylphosphatidylinositol (GPI) functions in the integration of GPI-anchored proteins into lipid microdomains. GPI anchor is biosynthesized from phosphatidylinositolcontaining unsaturated fatty acyl chains at the $s n-2$ position, and the lipid moieties of the GPI anchor are exchanged after 


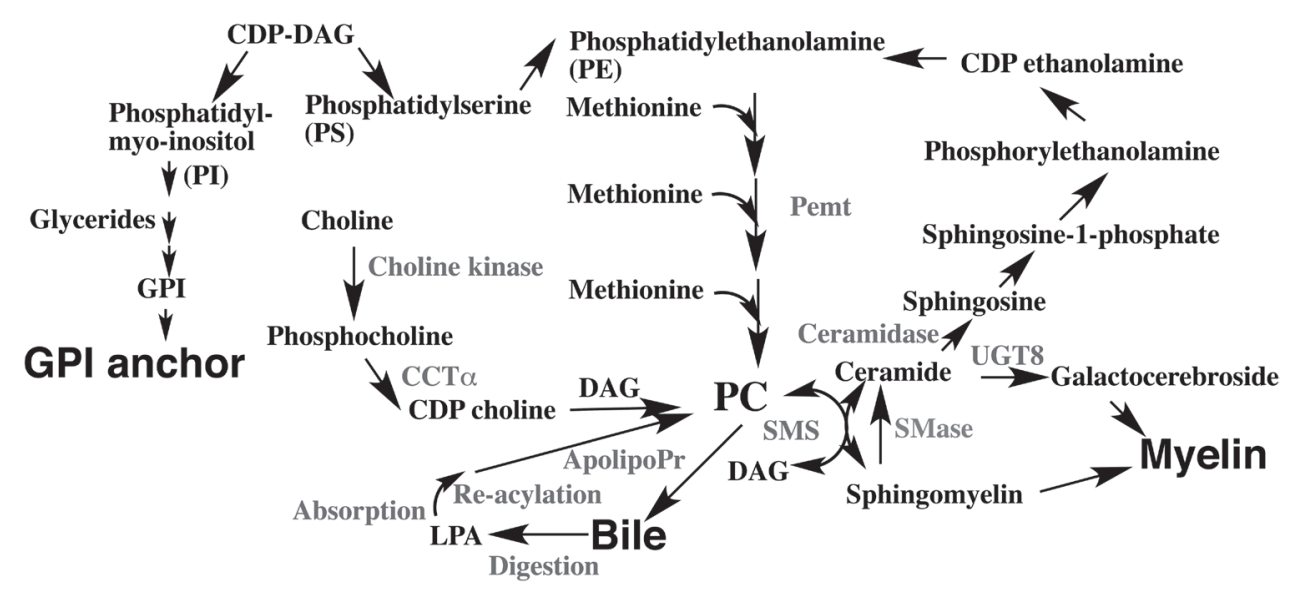

Fig. 4. Interrelationship of phospholipids and sphingolipids on their biosynthesis and recycling Enzymes and the associated biological processes are shown in gray color. ApolipoPr; apolipoprotein, CCT $\alpha$; CTP:phosphocholine cytidylyltransferase $\alpha$, CDP-choline; cytidine diphosphocholine, DAG; diacylglycerol, GPI; glycosylphosphatidylinositol, LPA; lysophosphatidic acid, PC; phosphatidylcholine, PE; phosphatidylethanolamine, PI; phosphatidylinositol, PS; phosphatidylserine, SMase; sphingomyelinase and UGT8; UDP-galactose ceramide galactosyltransferase.

GPI attachment to proteins in mammalian cells (Fig. 4). This lipid remodeling process of GPI-anchored proteins is essential for their association with the lipid microdomains ${ }^{160)}$.

Granule formation and apical sorting of digestive enzymes in pancreatic acinar cells involves the selective aggregation of a mixture of regulated secretory proteins and the association of these aggregates with specific membrane domains of the trans-Golgi network, which then pinch off as condensing vacuoles.

Isolated membranes of zymogen granules from pancreatic acinar cells are rich in cholesterol and sphingomyelin and formed detergent-insoluble complexes. These complexes contained the GPI-anchored glycoprotein GP-2, the lectin ZG16p, and sulfated matrix proteoglycans. Formation of zymogen granules as well as the formation of detergentinsoluble complexes was reduced after treatment of rat pancreatic lobules with $\mathrm{FB} 1^{103)}$. These results suggested the possible role of GPI-anchor in zymogen processing in the pancreas. GP-2-null mice, however, displayed no gross signs of nutrient malabsorption such as weight loss, growth retardation, or diarrhea ${ }^{161)}$. Zymogen granules in the GP-2 null mice appeared normal on electron microscopy and contained the normal complement of proteins excluding GP-2 ${ }^{161)}$. Therefore, the role of GPI anchoring on the FB1-mediated pancreatic toxicity remains obscure.

The folate receptor, like many glycosylphosphatidylinositol-anchored proteins, is found associated with membrane domains that are insoluble in Triton X-100 at low temperature and that are enriched in cholesterol and sphingolipids. The folate receptor-mediated transport of 5-methyltetrahy- drofolate was almost completely blocked in cells in which sphingolipids had been reduced by approximately $40 \%$ in Caco-2 cells after FB1-treatment. FB1 had no influence on the receptor-mediated transport or facilitative transport of the folate ${ }^{162)}$. FB1-treatment was shown to alter recycling of folate receptor in cell systems ${ }^{163)}$.

Maternal FB1 administration (20 mg/kg of b.w./day, i.p.) to pregnant $\mathrm{LM} / \mathrm{Bc}$ mice during early gestation resulted in $79 \%$ NTDs in exposed fetuses ${ }^{44)}$. Sphingolipid profiles were significantly altered in maternal and embryonic tissues following the exposure, and ${ }^{3} \mathrm{H}$-folate levels and immunohistochemical expression of GPI-anchored folate receptor were reduced. Maternal folate supplementation partially rescued the NTD phenotype, whereas intraperitoneal injections of a lipid raft component, GM1, significantly restored folate concentrations and afforded almost complete protection against FB1-induced NTDs. Maternal FB1 exposure is thus proposed to alter folate concentrations in $\mathrm{LM} / \mathrm{Bc}$ mice, resulting in a dose-dependent increase in NTDs.

Treatment with the same regimen of inbred mouse SWV strain, however, yielded different results. Approximately $15 \%$ of the implants were resorbed, and only one exencephalic fetus was observed in the $10 \mathrm{SWV}$ litters examined after the intraperitoneal administration of $20 \mathrm{mg} / \mathrm{kg}$ b.w./day on GD 7.5 and GD 8.5. A similar strain difference was also observed between CD1 and LM/Bc mice ${ }^{101,164)}$. CD1 mice exhibit an increased number of early embryonic resorptions and/or late fetal death following FB1 exposure, whereas LM/ Bc embryos survive, but fail to complete neurulation. 


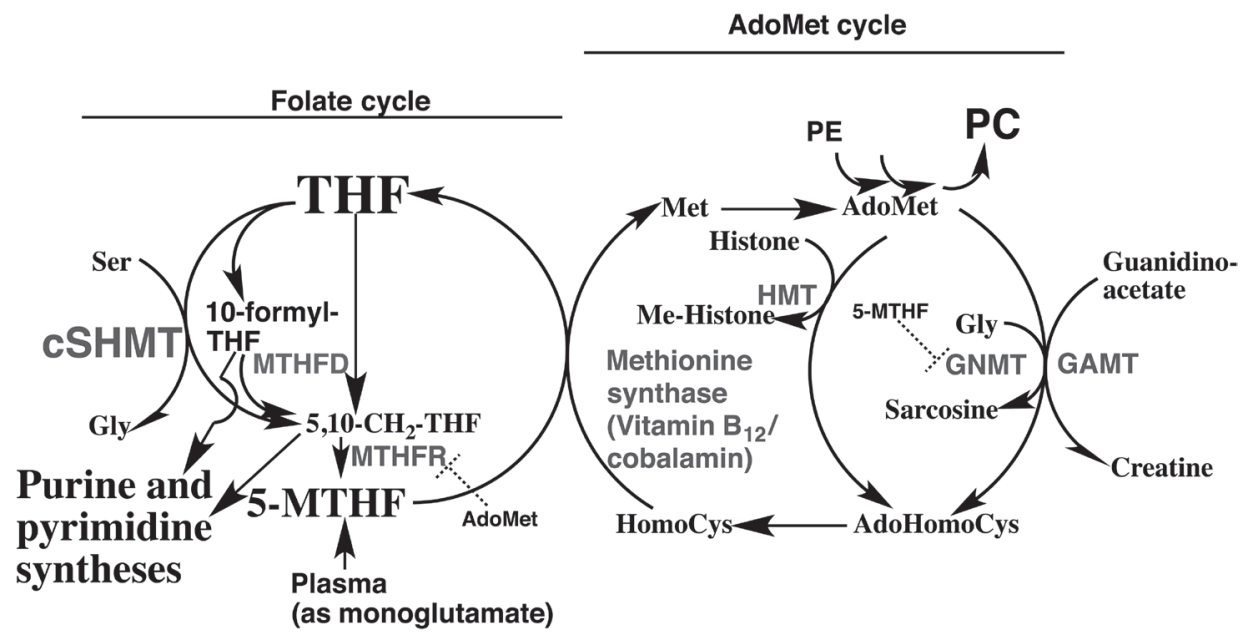

Fig. 5. Folate, cobalamin and methionine and their interactions

Cys; cysteine, Gly; glycine, Ser; serine, 5-MTHF; 5-methyltetrahydrofolate pentaglutamate, GNMT; glycine N-methyltransferase, HMT; histone methyltransferase, MTHFD; tetrahydrofolate dehydrogenase, MTHFR; methylenetetrahydrofolate reductase, cSHMT; cytosolic serine hydroxymethyl transferase, THF; tetrahydrofolate pentaglutamate, adoMet; S-adenosylmethionine. Dotted halt-signs indicate the feedback inhibition. Enzymes are shown in gray color.

\subsection{Interaction of Folate, Cobalamin and Methionine}

Folate, S-adenosylmethionine and cobalamin (vitamin B12) are key components of the one carbon unit (C1-unit) supply chain for nucleotide biosynthesis ${ }^{165)}$ (Fig. 5). Interruption of this supply chain is known to lead to embryo and developmental toxicities ${ }^{166,167)}$.

Female $\mathrm{LM} / \mathrm{Bc}$ mice fed folate-sufficient (control) or folate-deficient diet were treated intraperitoneally with 0 (vehicle), 2.5 or $10 \mathrm{mg} / \mathrm{kg} \mathrm{FB} 1$ on embryonic days 7 (E7) and E8, and their fetuses examined on E16. Dose-dependent NTD induction was found in groups fed the control diet: 3 of 13 low-FB1 dose and 10 of 11 high-FB1 dose litters were affected. Among groups fed folate-deficient diet, NTDs were found only in 4 of 11 high-FB1dose litters. In another trial, consumption of folate-deficient diet also resulted in fewer NTDs at a dose of $10 \mathrm{mg} / \mathrm{kg}$ of FB1 and reduced maternal red blood cell folate levels by $80 \%$. In utero death did not fully account for the differences in NTD rates. Thus, folate deficiency does not exacerbate FB1-mediated NTD formation in $\mathrm{LM} / \mathrm{Bc}$ mice ${ }^{168)}$.

Cobalamin can bind two carrier proteins in the digestive tract, haptocorrin (R protein) and intrinsic factor, but only the binding to intrinsic factor allows its absorption. Cobalamin is bound almost exclusively to haptocorrin in the acid milieu of the stomach, rather than to intrinsic factor. Cobalamin remains bound to haptocorrin in the slightly alkaline environment of the intestine until pancreatic proteases partially degrade haptocorrin and enable cobalamin to become bound exclusively to intrinsic factor ${ }^{169)}$.
In the aspirates from patients with exocrine pancreatic dysfunction, cobalamin was found to be coupled $>60 \%$ to a protein identical to $\mathrm{R}$ proteins in terms of molecular mass (125,000), ionic nature (mean pI, 3.51), and also of the reactivity with anti-R protein and anti-intrinsic factor sera. These findings suggest that the formation of unabsorbable cobalamin complexes may be a reason for the impaired cobalamin absorption in exocrine pancreatic insufficiency. Decreased enzyme activity and nondegradation of $\mathrm{R}$ proteins may also be due to malactivation of pancreatic zymogens in an acidic $\mathrm{pH}$ of the intestinal juice ${ }^{170)}$. In another study of patients showing malabsorption of cobalamin with exocrine pancreatic insufficiency, a failure to degrade haptocorrin is proposed to prevent the binding of cobalamin to intrinsic factor ${ }^{171)}$. Thus currently plural types of $\mathrm{C} 1$-unit dysfunctions are possible causes of developmental toxicity after FB1 exposure $^{101)}$.

\subsection{Myelin}

Long-term deficiency of cobalamin or folate causes a demyelinating disease of the brain and spinal cord ${ }^{172)}$. A reduced supply of methyl groups has been implicated as the mechanism of demyelination from human studies of inborn errors. One child had abnormal methylfolate metabolism, one had abnormal methylcobalamin metabolism, and one had hypermethioninaemia probably caused by methionine adenosyltransferase deficiency. Each patient had abnormal myelination before treatment, suggesting demyelination with low cerebrospinal concentration of S-adenosylmethionine. Treatment with L-methionine or betaine led to substantial 
clinical improvement, apparent remyelination, and increases in cerebrospinal S-adenosylmethionine concentration into the normal range ${ }^{172)}$. Thus, expected decrease in circulating methionine level in FB1-exposed animals could be linked to the brain dysfunction.

Myelin is a fatty white substance surrounding the axon of nerve cells ${ }^{173,174)}$. The primary lipid of myelin is glycolipid called galactocerebroside. UGT8 enzymes ${ }^{175)}$ (UDP-galactose ceramide galactosyltransferases) catalyze transfer of galactose to ceramide to form galactocerebrosides (Fig. 4). Amounts of compacted myelin as well as myelin binding protein and myelin specific sphingolipids are decreased in CerS2-deficient mice carrying an insertion (gene trap) in the CerS2 gene ${ }^{114)}$. CerS2 is localized to white matter of the brain and capable of synthesizing myelin sphingolipids ${ }^{176)}$ These results suggest the possible involvement of FB1mediated suppression of brain CerS2 in myelin dysfunction. Sphingomyelin is also contained in the membranous myelin sheath surrounding nerve cell axons, where it serves as an electrically insulating layer.

Myelination starts at birth in the spinal cord in the mouse, and is achieved in almost all regions of the brain around 45-60 days postnatally ${ }^{173)}$. In humans, the peak of myelin formation occurs during the first year postnatally ${ }^{177)}$, although it starts during the second half of fetal life in the spinal cord. These results may suggest the high susceptibility to FB1 during developing ages. Decreased production of ceramides would lead to reduced levels of galactocerebroside and PC/sphingomyelin, which may be associated with equine leukoencephalomalacia and swine pulmonary edema, respectively.

\section{Roles of PC Mobilization and of Methionine-deficiency in FB1-mediated Toxicity}

FB1 shows multiple organ toxicities in experimental and domestic animals. Toxicities like leukoencephalomalacia and pulmonary edema are unique and species-specific, but nephrotoxicity occurs in many species and hepatotoxicity appears in all species examined. Profiles of biochemical parameters suggest the suppressed bile excretory function possibly due to the deficiency of PC supply as the initial event of FB1-mediated liver toxicity as described above.

Typical pathological models of liver toxicity are related to phospholipid dysfunctions in rodents. One model is the Pemt-null mouse fed a choline-deficient $\operatorname{diet}^{131)}$, and the second is rat and mouse fed choline-deficient diet with ethionine supplementation ${ }^{140-142)}$. The third model is mouse fed a diet deficient of both choline and methionine. The first model showed severe liver disorders to lead to death within one week. The second model is characterized with both liver and pancreas damages. The third is a typical NASH (nonalcoholic steatohepatitis) model ${ }^{98,178)}$. These models yield consistently deficient conditions of both CDP-choline and methyl donor for PE methylation.

Total phospholipids account for roughly $2-3 \%$ wet weight of liver of mouse and the half is $\mathrm{PC}^{179)}$. Thus, total hepatic amount of PC would be around 20-30 mg in 1-2 g of liver of $20 \mathrm{~g}$ body weight of mouse. Apparently, the mouse liver secretes the equivalent of its entire hepatic pool of PC into bile daily. Most of the PC is reabsorbed through the intestine as LPA and is returned to the liver and other tissues after the reacylation. Administration of methionine was unable to prevent FB1-mediated liver toxicity in rats ${ }^{180)}$, although methionine partly prevented an increase of sphingosine, but not sphinganine. Therefore, decreased recycling of PC, excreted in the intestine through the bile, is likely the main mechanism for the FB1-mediated deficiency of hepatic PC. No clear information is available at present on the initial disorder to lead to malabsorption of phospholipids in FB1-treated animals. Plural candidates are discussed in this context. 1) Altered functions of sPLA2 are possible to occur. Functional sPLA2 requires submillimolar concentration of calcium ion for the maximal catalysis, but the chelating of carballylic acid part of FB1 with calcium ion may lower the efficiency of the catalysis as a direct interaction of FB1. 2) Similar to rodents fed CDE diet, FB1 causes lesions of the pancreas as well as liver in rats and pigs. If discharge of digestive enzymes is blocked and zymogen granules accumulated within acinar cells of pancreas in FB1-treated animals, reabsorption of PC would be decreased even considering the compensation through other PLA2 forms. The supply of ethionine is critical in pancreas lesion in the CDE model. Auxiliary synthesis of PC from PE in livers of FB1-treated animals would consume methionine entering through portal vein and thus diminish the amount available through the systemic circulation. This may produce a situation similar to animals treated with CDE diet or diet deficient both choline and methionine as described above.

In addition to the three in vivo models described above, administration of thioacetamide is reported to elicit the hepatotoxicity ${ }^{181)}$ and encephalopathy ${ }^{182)}$ in rats. Brain levels of sphingomyelin and phosphatidylinositol are decreased in thioacetamide-treated rats. Similar to the CDE diet model, the hepatotoxicity was ameliorated by the coadministration of S-adenosylmethionine intraperitoneally in thioacetamideexposed animals ${ }^{183)}$. Thioacetamide is reported to reduce levels of liver-specific methionine adenyltransferase and DNA methylation ${ }^{184)}$. These data also support the idea that 
methionine and phospholipid are associated with liver and brain toxicities.

On the association of methionine deficiency with pancreatic disorders, S-adenosylmethionine was shown to suppress autophagy through the action of methyltransferase Ppm1p in yeast ${ }^{185)}$. The enzyme modifies the catalytic subunit of PP2A. Lysosomal/autophagic dysfunction was proposed to be a key-initiating event in pancreatitis and cancer ${ }^{186,187)}$. CerS2 down-regulation is also reported to lead to autophagy in cell culture systems ${ }^{188)}$. Autophagosome half-life in mammalian cells is within $10 \mathrm{~min}$, although impaired autophagic flux prolongs the half-life ${ }^{189}$ ). Thus, careful examination may be necessary to detect an alteration of pancreas in FB1-treated animals.

FB1 interacts with ceramide synthases (sphingosine $\mathrm{N}$-acyltransfeases) to inhibit $\mathrm{N}$-acylations of sphinganine to form dihydroceramides, and of sphingosine to form ceramides (Fig. 2). Sphingomyelin synthase (SMS) mediates the biosynthesis of sphingomyelin from ceramides and PC. Human SMS1 and SMS2, rather than functioning strictly as sphingomyelin synthases, are capable of using sphingomyelin and PC as phosphocholine donors to produce PC or sphingomyelin, dependent on the relative concentrations of diacylglycerides (DAG) and ceramide as phosphocholine acceptors, respectively ${ }^{190)}$. Both SMS1 and SMS2 are ubiquitously expressed ${ }^{190)}$. SMS1 is associated with the Golgi apparatus, while SMS2 is primarily concentrated at the plasma membrane. The reverse transfer of phosphocholine is detected in various mammalian cells ${ }^{191-193)}$, and syntheses of PC and sphingomyelin are physiologically linked ${ }^{194)}$. SMSmediated transfer of phosphocholyl group thus may be an additional pathway for supplying PC in tissues like the liver. Decreased levels of sphingomyelin and increased levels of ceramide or sphingosine are detected in livers of FB1-treated mice $^{23)}$, rats $^{136)}$ and pigs ${ }^{14)}$, which may be indicative of the adaptive changes to lead to their liver disorders.

PC is a component of high-density lipoprotein ${ }^{195)}$. Exchanges of PC thus occur through serum lipoproteins among tissues. PC is the predominant phospholipid of alveolar surfactant. Decreased availability of PC as a cellular membrane component, and also as a phosphocholine-donor for sphingomyelin synthesis may be linked to disorders in peripheral tissues such as the kidney and lung in FB1-treated animals. In addition, formation of PC from sphingomyelin would produce ceramides as byproducts. Excess ceramides are metabolized to sphingosine as well as galactocerebroside. Sphingosine and sphinganine are degraded to form ethanolamine phosphate and fatty aldehydes like palmitoic aldehyde. The former is used for the synthesis of PE, whereas the latter may be involved in the oxidative damage that occurs in tar- get tissues. The high demands for PC supply in liver force the mobilization of PC from tissues through plasma components like high-density lipoprotein (HDL), and also the exchange of phosphocholine moiety between sphingomyelin and PC in tissues. Prolonged shifts in phospholipid flow may trigger the signal for FB1-mediated toxicological events.

Myelin is a fatty white substance surrounding the axons of nerve cells ${ }^{173,174)}$. The primary lipid of myelin is a glycolipid called galactocerebroside. UGT8 enzymes ${ }^{175)}$ (UDP-galactose ceramide galactosyltransferases) catalyze transfer of galactose to ceramide to form galactocerebrosides. Production of galactocerebroside is necessary for myelination and FB1-mediated changes in the composition of myelin is possibly associated with brain disorders. In fact, the amounts of compacted myelin as well as myelin binding protein and myelin specific sphingolipids are decreased in CerS2-deficient mice carrying an insertion (gene trap) in the CerS2 gene ${ }^{114)}$. CerS2 is localized to white matter of the brain and capable of synthesizing myelin sphingolipids ${ }^{176)}$ These results suggest the possible involvement of FB1-mediated suppression of brain CerS2 in equine leukoencephalomalacia. In contrast, no embryonic or prenatal abnormalities have been detected in CerS2 null mice ${ }^{115,196)}$.

Sphinganine, sphingosine and the ratio are clearly increased in CerS2-deficient mice in both the liver and kidney, but only the liver toxicity, without kidney pathology, is observed $^{196)}$. These data may be indicative of sphinganine and sphingosine as surrogate marker of the tissue exposure, but accumulation of both substances themselves is not directly linked to the toxicological events at least in the kidney. Alternatively, subsequent metabolism such as formation of sphingosine-1-phosphate may evoke cellular signals. CerS2, having sphingosine-1-phosphate receptor-like motifs in its sequence ${ }^{111}$, may be regulated in vivo by sphingosine1-phosphate ${ }^{110}$ ). Therefore altered signaling through sphingolipids, and the irregular metabolisms may be associated with chronic toxicities of FB1 as the studies of CerS2-deficient mice suggested ${ }^{114,115)}$. Progress in quantitative analyses of biochemical consequence of phospholipid flows and signals would help us to clarify the detailed mechanisms of FB1mediated toxicity. 


\section{Reference}

1. Gelderblom WC, Jaskiewicz K, Marasas WF, et al. Fumonisins--novel mycotoxins with cancer-promoting activity produced by Fusarium moniliforme. Appl Environ Microbiol. 1988; 54: 1806-1811. PMID: 2901247

2. Kriek NP, Kellerman TS, Marasas WF. A comparative study of the toxicity of Fusarium verticillioides (= F. moniliforme) to horses, primates, pigs, sheep and rats. Onderstepoort $J$ Vet Res. 1981; 48: 129-131. PMID: 7312307

3. Kriek NP, Marasas WF, Thiel PG. Hepato- and cardiotoxicity of Fusarium verticillioides (F. moniliforme) isolates from Southern African maize. Food Cosmet Toxicol. 1981; 19: 447456. PMID: 7274878 doi: 10.1016/0015-6264(81)90449-1

4. Bezuidenhout SC, Gelderblom WCA, Gorst-Allman CP, et al. Structure elucidation of the fumonisins, mycotoxins from Fusarium moniliforme. Chem Commun. 1988; 743-745. doi: $10.1039 / \mathrm{c} 39880000743$

5. Ito $\mathrm{Y}$, Tsurufuji $\mathrm{S}$, Ishibashi $\mathrm{S}$, Ishidate $\mathrm{M}$, Tamura $\mathrm{Z}$, Takita H. Detoxication and excretion of radioactive strontium. III. Effect of tricarballylic and lactic acids. Chem Pharm Bull (Tokyo). 1958; 6: 34-36. PMID: 13537146 doi: 10.1248/cpb.6.34

6. Beier RC, Elissalde MH, Stanker LH. Calculated three dimensional structures of the fumonisin B1-4 mycotoxins. Bull Environ Contam Toxicol. 1995; 54: 479-487. PMID: 7767023 doi: 10.1007/BF00192588

7. Merrill AH Jr, van Echten G, Wang E, Sandhoff K. Fumonisin $\mathrm{B} 1$ inhibits sphingosine (sphinganine) $\mathrm{N}$-acyltransferase and de novo sphingolipid biosynthesis in cultured neurons in situ. J Biol Chem. 1993; 268: 27299-27306. PMID: 8262970

8. Fukuda H, Shima H, Vesonder RF, et al. Inhibition of protein serine/threonine phosphatases by fumonisin B1, a mycotoxin. Biochem Biophys Res Commun. 1996; 220: 160-165. PMID: 8602837 doi: 10.1006/bbrc. 1996.0374

9. Jenkins GR, Tolleson WH, Newkirk DK, et al. Identification of fumonisin B1 as an inhibitor of argininosuccinate synthetase using fumonisin affinity chromatography and in vitro kinetic studies. J Biochem Mol Toxicol. 2000; 14: 320-328. PMID: 11083085

10. Howard PC, Couch LH, Patton RE, et al. Comparison of the toxicity of several fumonisin derivatives in a 28 -day feeding study with female B6C3F(1) mice. Toxicol Appl Pharmacol. 2002; 185: 153-165. PMID: 12498732 doi: 10.1006/ taap.2002.9529

11. Bulder AS, Arcella D, Bolger M, et al. Fumonisins (addendum). In: WHO, ed. Safety evaluation of certain food additives and contaminants. Vol 65. Geneva 2012: 325-794.

12. Marasas WF. Discovery and occurrence of the fumonisins: a historical perspective. Environ Health Perspect. 2001; 109 (Suppl 2): 239-243. PMID: 11359691 doi: 10.1289/ ehp.01109s2239

13. Voss KA, Riley RT. Fumonisin Toxicity and Mechanism of Action: Overview and Current Perspectives. Food Safety. 2013; 1: 49-69. doi: 10.14252/foodsafetyfscj.2013006

14. Loiseau N, Polizzi A, Dupuy A, et al. New insights into the organ-specific adverse effects of fumonisin B1: comparison between lung and liver. Arch Toxicol. 2015; 89: 1619-1629. PMID: 25155190 doi: 10.1007/s00204-014-1323-6
15. Hahn I, Nagl V, Schwartz-Zimmermann HE, et al. Effects of orally administered fumonisin $\mathrm{B}_{1}\left(\mathrm{FB}_{1}\right)$, partially hydrolysed $\mathrm{FB}_{1}$, hydrolysed $\mathrm{FB}_{1}$ and $\mathrm{N}$-(1-deoxy-D-fructos-1-yl) $\mathrm{FB}_{1}$ on the sphingolipid metabolism in rats. Food Chem Toxicol. 2015; 76: 11-18. PMID: 25475052 doi: 10.1016/j.fct.2014.11.020

16. Voss KA, Riley RT, Snook ME, Waes JG. Reproductive and sphingolipid metabolic effects of fumonisin $\mathrm{B}(1)$ and its alkaline hydrolysis product in $\mathrm{LM} / \mathrm{Bc}$ mice: hydrolyzed fumonisin B(1) did not cause neural tube defects. Toxicol Sci. 2009; 112: 459-467. PMID: 19783636 doi: $10.1093 /$ toxsci/kfp215

17. The Nomenclature of Lipids The nomenclature of lipids. $J$ Lipid Res. 1967; 8: 523-528. PMID: 6049680

18. IUPAC-IUB Commission on Biochemical Nomenclature (CBN) The nomenclature of lipids. Eur J Biochem. 1967; 2: 127-131. PMID: 6078528

19. Merrill Jr AH. Sphingolipid and glycosphingolipid metabolic pathways in the era of sphingolipidomics. Chem Rev. 2011; 111: 6387-6422. PMID: 21942574 doi: 10.1021/cr2002917

20. Spiegel S, Milstien S. Sphingosine-1-phosphate: an enigmatic signalling lipid. Nat Rev Mol Cell Biol. 2003; 4: 397-407. PMID: 12728273 doi: 10.1038/nrm1103

21. Pyne NJ, Pyne S. Sphingosine 1-phosphate and cancer. Nat Rev Cancer. 2010; 10: 489-503. PMID: 20555359 doi: $10.1038 / \mathrm{nrc} 2875$

22. Mao C, Obeid LM. Ceramidases: regulators of cellular responses mediated by ceramide, sphingosine, and sphingosine1-phosphate. Biochim Biophys Acta. 2008; 1781: 424-434.

23. He Q, Suzuki H, Sharma N, Sharma RP. Ceramide synthase inhibition by fumonisin B1 treatment activates sphingolipidmetabolizing systems in mouse liver. Toxicol Sci. 2006; 94: 388-397. PMID: 16960033 doi: 10.1093/toxsci/kfl102

24. Sharma RP, He Q, Riley RT. Lupus-prone NZBWF1/J mice, defective in cytokine signaling, are resistant to fumonisin hepatotoxicity despite accumulation of liver sphinganine. Toxicology. 2005; 216: 59-71. PMID: 16159691 doi: 10.1016/j. tox.2005.07.024

25. Merrill AH Jr, Sullards MC, Wang E, Voss KA, Riley RT. Sphingolipid metabolism: roles in signal transduction and disruption by fumonisins. Environ Health Perspect. 2001; 109 (Suppl 2): 283-289. PMID: 11359697 doi: 10.1289/ ehp.01109s2283

26. Martinez-Larranaga MR, Anadon A, Diaz MJ, et al. Toxicokinetics and oral bioavailability of fumonisin B1. Vet Hum Toxicol. 1999; 41: 357-362. PMID: 10592940

27. Kwon OS, Sandberg JA, Slikker W Jr. Effects of fumonisin B1 treatment on blood-brain barrier transfer in developing rats. Neurotoxicol Teratol. 1997; 19: 151-155. PMID: 9136132 doi: 10.1016/S0892-0362(96)00217-6

28. Shephard GS, Thiel PG, Sydenham EW. Initial studies on the toxicokinetics of fumonisin B1 in rats. Food Chem Toxicol. 1992; 30: 277-279. PMID: 1628862 doi: 10.1016/02786915(92)90004-5

29. Alberts JF, Gelderblom WC, Vleggaar R, Marasas WF, Rheeder JP. Production of [14C]fumonisin B1 by Fusarium moniliforme MRC 826 in corn cultures. Appl Environ Microbiol. 1993; 59: 2673-2677. PMID: 8368853

30. Shephard GS, Thiel PG, Sydenham EW, Alberts JF. Biliary excretion of the mycotoxin fumonisin B1 in rats. Food Chem Toxicol. 1994; 32: 489-491. PMID: 8206448 doi: 10.1016/0278-6915(94)90047-7 
31. Norred WP, Plattner RD, Chamberlain WJ. Distribution and excretion of [14C]fumonisin B1 in male Sprague-Dawley rats. Nat Toxins. 1993; 1: 341-346. PMID: 8167955

32. Hopmans EC, Hauck CC, Hendrich S, Murphy PA. Excretion of fumonisin B1, hydrolyzed fumonisin B1, and the fumonisin B1-fructose adduct in rats. J Agric Food Chem. 1997; 45: 2618-2625. doi: 10.1021/jf960886j

33. Prelusky DB, Trenholm HL, Savard ME. Pharmacokinetic fate of 14C-labelled fumonisin B1 in swine. Nat Toxins. 1994; 2: 73-80. PMID: 8075896 doi: 10.1002/nt.2620020205

34. Voss KA, Smith GW, Haschek WM. Fumonisins: Toxicokinetics, mechanism of action and toxicity. Anim Feed Sci Technol. 2007; 137: 299-325. doi: 10.1016/j.anifeedsci.2007.06.007

35. Dilkin P, Direito G, Simas MM, Mallmann CA, Corrêa B. Toxicokinetics and toxicological effects of single oral dose of fumonisin B1 containing Fusarium verticillioides culture material in weaned piglets. Chem Biol Interact. 2010; 185: 157-162. PMID: 20338158 doi: 10.1016/j.cbi.2010.03.025

36. Fodor J, Balogh K, Weber M, et al. Absorption, distribution and elimination of fumonisin $\mathrm{B}(1)$ metabolites in weaned piglets. Food Addit Contam Part A Chem Anal Control Expo Risk Assess. 2008; 25: 88-96. PMID: 18041597 doi: $10.1080 / 02652030701546180$

37. Meyer K, Mohr K, Bauer J, Horn P, Kovács M. Residue formation of fumonisin B1 in porcine tissues. Food $A d$ dit Contam. 2003; 20: 639-647. PMID: 12888389 doi: $10.1080 / 0265203031000119043$

38. Shephard GS, Thiel PG, Sydenham EW, Alberts JF, Cawood ME. Distribution and excretion of a single dose of the mycotoxin fumonisin B1 in a non-human primate. Toxicon. 1994; 32: 735-741. PMID: 7940579 doi: 10.1016/00410101(94)90342-5

39. Riley RT, Torres O, Showker JL, et al. The kinetics of urinary fumonisin B1 excretion in humans consuming maizebased diets. Mol Nutr Food Res. 2012; 56: 1445-1455. PMID: 22815244 doi: 10.1002/mnfr.201200166

40. Cawood ME, Gelderblom WC, Alberts JF, Snyman SD. Interaction of 14C-labelled fumonisin B mycotoxins with primary rat hepatocyte cultures. Food Chem Toxicol. 1994; 32: 627632. PMID: 8045475 doi: 10.1016/0278-6915(94)90006-X

41. Sharma RP, Bhandari N, Tsunoda M, Riley RT, Voss KA, Meredith FI. Fumonisin toxicity in a transgenic mouse model lacking the mdrla/lb P-glycoprotein genes. Environ Toxicol Pharmacol. 2000; 8: 173-182. PMID: 10925070 doi: 10.1016/ S1382-6689(00)00038-7

42. De Angelis I, Friggè G, Raimondi F, Stammati A, Zucco F, Caloni F. Absorption of fumonisin B1 and aminopentol on an in vitro model of intestinal epithelium; the role of P-glycoprotein. Toxicon. 2005; 45: 285-291. PMID: 15683866 doi: 10.1016/j.toxicon.2004.10.015

43. Voss KA, Bacon CW, Norred WP, et al. Studies on the reproductive effects of Fusarium moniliforme culture material in rats and the biodistribution of [14C] fumonisin B1 in pregnant rats. Nat Toxins. 1996; 4: 24-33. PMID: 8680750 doi: 10.1002/19960401NT4

44. Gelineau-van Waes J, Starr L, Maddox J, et al. Maternal fumonisin exposure and risk for neural tube defects: mechanisms in an in vivo mouse model. Birth Defects Res A Clin Mol Teratol. 2005; 73: 487-497. PMID: 15959874 doi: 10.1002/bdra.20148
45. Sekine T, Cha SH, Endou H. The multispecific organic anion transporter (OAT) family. Pflugers Arch. 2000; 440: 337-350. PMID: 10954321 doi: 10.1007/s004240000297

46. Tachampa K, Takeda M, Khamdang S, et al. Interactions of organic anion transporters and organic cation transporters with mycotoxins. J Pharmacol Sci. 2008; 106: 435-443. PMID: 18319568 doi: 10.1254/jphs.FP0070911

47. Agarwal S, Uchida Y, Mittapalli RK, Sane R, Terasaki T, Elmquist WF. Quantitative proteomics of transporter expression in brain capillary endothelial cells isolated from Pglycoprotein (P-gp), breast cancer resistance protein (Bcrp), and P-gp/Bcrp knockout mice. Drug Metab Dispos. 2012; 40: 1164-1169. PMID: 22401960 doi: 10.1124/dmd.112.044719

48. Gutmann H, Hruz P, Zimmermann C, Beglinger C, Drewe J. Distribution of breast cancer resistance protein (BCRP/ ABCG2) mRNA expression along the human GI tract. Biochem Pharmacol. 2005; 70: 695-699. PMID: 15998509 doi: 10.1016/j.bcp.2005.05.031

49. Voss KA, Chamberlain WJ, Bacon CW, Herbert RA, Walters DB, Norred WP. Subchronic feeding study of the mycotoxin fumonisin $\mathrm{B} 1$ in $\mathrm{B} 6 \mathrm{C} 3 \mathrm{~F} 1$ mice and Fischer 344 rats. Fundam Appl Toxicol. 1995; 24: 102-110. PMID: 7713333 doi: 10.1006/faat.1995.1012

50. NTP. NTP technical report on the toxicology and carcinogenesis studies of fumonisin B1 (cas no. 116355-83-0) in F344/N rats and B6C3F1 mice (feed studies). Department of health and human services Public health service National institutes of health; 2001:1-355.

51. Bondy GS, Suzuki CA, Fernie SM, et al. Toxicity of fumonisin B1 to B6C3F1 mice: a 14-day gavage study. Food Chem Toxicol. 1997; 35: 981-989. PMID: 9463532 doi: 10.1016/ S0278-6915(97)87267-5

52. Tolleson WH, Dooley KL, Sheldon WG, Thurman JD, Bucci TJ, Howard PC. The mycotoxin fumonisin induces apoptosis in cultured human cells and in livers and kidneys of rats. Adv Exp Med Biol. 1996; 392: 237-250. PMID: 8850621 doi: 10.1007/978-1-4899-1379-1_21

53. Voss KA, Chamberlain WJ, Bacon CW, Norred WP. A preliminary investigation on renal and hepatic toxicity in rats fed purified fumonisin B1. Nat Toxins. 1993; 1: 222-228. PMID: 8167938 doi: 10.1002/nt.2620010404

54. Voss KA, Plattner RD, Riley RT, Meredith FI, Norred WP. In vivo effects of fumonisin B1-producing and fumonisin B1-nonproducing Fusarium moniliforme isolates are similar: fumonisins B2 and B3 cause hepato- and nephrotoxicity in rats. Mycopathologia. 1998; 141: 45-58. PMID: 9725030 doi: 10.1023/A:1006810916344

55. Riley RT, Voss KA. Differential sensitivity of rat kidney and liver to fumonisin toxicity: organ-specific differences in toxin accumulation and sphingoid base metabolism. Toxicol Sci. 2006; 92: 335-345. PMID: 16613836 doi: 10.1093/toxsci/ kfj198

56. Bondy GS, Suzuki CA, Mueller RW, et al. Gavage administration of the fungal toxin fumonisin B1 to female SpragueDawley rats. J Toxicol Environ Health A. 1998; 53: 135-151. PMID: 9444317 doi: 10.1080/009841098159411

57. Bondy G, Barker M, Mueller R, et al. Fumonisin B1 toxicity in male Sprague-Dawley rats. Adv Exp Med Biol. 1996; 392: 251-264. PMID: 8850622 doi: 10.1007/978-1-4899-1379$1 \_22$ 
58. Bondy G, Suzuki C, Barker M, et al. Toxicity of fumonisin B1 administered intraperitoneally to male Sprague-Dawley rats. Food Chem Toxicol. 1995; 33: 653-665. PMID: 7672738 doi: 10.1016/0278-6915(95)00031-V

59. Gumprecht LA, Marcucci A, Weigel RM, et al. Effects of intravenous fumonisin B1 in rabbits: nephrotoxicity and sphingolipid alterations. Nat Toxins. 1995; 3: 395-403. PMID: 8581326 doi: 10.1002/nt.2620030512

60. Harrison LR, Colvin BM, Greene JT, Newman LE, Cole JR Jr. Pulmonary edema and hydrothorax in swine produced by fumonisin B1, a toxic metabolite of Fusarium moniliforme. $J$ Vet Diagn Invest. 1990; 2: 217-221. PMID: 2094448 doi: $10.1177 / 104063879000200312$

61. Colvin BM, Harrison LR. Fumonisin-induced pulmonary edema and hydrothorax in swine. Mycopathologia. 1992; 117: 79-82. PMID: 1513376 doi: 10.1007/BF00497282

62. Colvin BM, Cooley AJ, Beaver RW. Fumonisin toxicosis in swine: clinical and pathologic findings. $J$ Vet Diagn Invest. 1993; 5: 232-241. PMID: 8507702

63. Gumprecht LA, Beasley VR, Weigel RM, et al. Development of fumonisin-induced hepatotoxicity and pulmonary edema in orally dosed swine: morphological and biochemical alterations. Toxicol Pathol. 1998; 26: 777-788. PMID: 9864095 doi: $10.1177 / 019262339802600610$

64. Haschek WM, Motelin G, Ness DK, et al. Characterization of fumonisin toxicity in orally and intravenously dosed swine. Mycopathologia. 1992; 117: 83-96. PMID: 1387461 doi: 10.1007/BF00497283

65. Haschek WM, Gumprecht LA, Smith G, Tumbleson ME, Constable PD. Fumonisin toxicosis in swine: an overview of porcine pulmonary edema and current perspectives. Environ Health Perspect. 2001; 109 (Suppl 2): 251-257. PMID: 11359693 doi: 10.1289/ehp.01109s2251

66. Kellerman TS, Marasas WF, Pienaar JG, Naudé TW. A mycotoxicosis of equidae caused by Fusarium moniliforme sheldon. A preliminary communication. Onderstepoort $J$ Vet Res. 1972; 39: 205-208. PMID: 4664322

67. Marasas WF, Kellerman TS, Pienaar JG, Naudé TW. Leukoencephalomalacia: a mycotoxicosis of Equidae caused by Fusarium moniliforme Sheldon. Onderstepoort J Vet Res. 1976; 43: 113-122. PMID: 1012650

68. Marasas WF, Kellerman TS, Gelderblom WC, Coetzer JA, Thiel PG, van der Lugt JJ. Leukoencephalomalacia in a horse induced by fumonisin B1 isolated from Fusarium moniliforme. Onderstepoort J Vet Res. 1988; 55: 197-203. PMID: 3217091

69. Foreman JH, Constable PD, Waggoner AL, et al. Neurologic abnormalities and cerebrospinal fluid changes in horses administered fumonisin B1 intravenously. J Vet Intern Med. 2004; 18: 223-230. PMID: 15058775 doi: 10.1111/j.19391676.2004.tb00165.x

70. Gross SM, Reddy RV, Rottinghaus GE, Johnson G, Reddy CS. Developmental effects of fumonisin B1-containing Fusarium moniliforme culture extract in CD1 mice. Mycopathologia. 1994; 128: 111-118. PMID: 7777035 doi: 10.1007/ BF01103018

71. Floss JL, Casteel SW, Johnson GC, Rottinghaus GE, Krause GF. Development toxicity of fumonisin in Syrian hamsters. Mycopathologia. 1994; 128: 33-38. PMID: 7708090 doi: 10.1007/BF01104276
72. Penner JD, Casteel SW, Pittman L Jr, Rottinghaus GE, Wyatt RD. Developmental toxicity of purified fumonisin B1 in pregnant Syrian hamsters. J Appl Toxicol. 1998; 18: 197-203. PMID: 9685049 doi: 10.1002/(SICI)10991263(199805/06)18:3<197::AID-JAT497>3.0.CO;2-R

73. Reddy RV, Johnson G, Rottinghaus GE, Casteel SW, Reddy CS. Developmental effects of fumonisin B1 in mice. Mycopathologia. 1996; 134: 161-166. PMID: 8981781

74. Collins TF, Shackelford ME, Sprando RL, et al. Effects of fumonisin B1 in pregnant rats. Food Chem Toxicol. 1998; 36: 397-408. PMID: 9662415 doi: 10.1016/S0278-6915(97)00170-1

75. Collins TF, Sprando RL, Black TN, et al. Effects of fumonisin B1 in pregnant rats. Part 2. Food Chem Toxicol. 1998; 36: 673685. PMID: 9734718 doi: 10.1016/S0278-6915(98)00036-2

76. Javed T, Bennett GA, Richard JL, Dombrink-Kurtzman MA, Côté LM, Buck WB. Mortality in broiler chicks on feed amended with Fusarium proliferatum culture material or with purified fumonisin B1 and moniliformin. Mycopathologia. 1993; 123: 171-184. PMID: 8302366 doi: 10.1007/ BF01111269

77. Zacharias C, van Echten-Deckert G, Wang E, Merrill AH Jr, Sandhoff K. The effect of fumonisin B1 on developing chick embryos: correlation between de novo sphingolipid biosynthesis and gross morphological changes. Glycoconj J. 1996; 13: 167-175. PMID: 8737241 doi: 10.1007/BF00731491

78. LaBorde JB, Terry KK, Howard PC, et al. Lack of embryotoxicity of fumonisin B1 in New Zealand white rabbits. Fundam Appl Toxicol. 1997; 40: 120-128. PMID: 9398494 doi: 10.1006/faat.1997.2380

79. Flynn TJ, Stack ME, Troy AL, Chirtel SJ. Assessment of the embryotoxic potential of the total hydrolysis product of fumonisin B1 using cultured organogenesis-staged rat embryos. Food Chem Toxicol. 1997; 35: 1135-1141. PMID: 9449218 doi: 10.1016/S0278-6915(97)85466-X

80. Missmer SA, Suarez L, Felkner M, et al. Exposure to fumonisins and the occurrence of neural tube defects along the Texas-Mexico border. Environ Health Perspect. 2006; 114: 237-241. PMID: 16451860 doi: 10.1289/ehp.8221

81. Hendricks K. Fumonisins and neural tube defects in South Texas. Epidemiology. 1999; 10: 198-200. PMID: 10069261

82. Sadler TW, Merrill AH, Stevens VL, Sullards MC, Wang E, Wang P. Prevention of fumonisin B1-induced neural tube defects by folic acid. Teratology. 2002; 66: 169-176. PMID: 12353213 doi: 10.1002/tera.10089

83. Zhang Y, Klaassen CD. Effects of feeding bile acids and a bile acid sequestrant on hepatic bile acid composition in mice. J Lipid Res. 2010; 51: 3230-3242. PMID: 20671298 doi: 10.1194/j1r.M007641

84. Faubion WA, Guicciardi ME, Miyoshi H, et al. Toxic bile salts induce rodent hepatocyte apoptosis via direct activation of Fas. J Clin Invest. 1999; 103: 137-145. PMID: 9884343 doi: 10.1172/JCI4765

85. Jones B, Roberts PJ, Faubion WA, Kominami E, Gores GJ. Cystatin A expression reduces bile salt-induced apoptosis in a rat hepatoma cell line. Am J Physiol. 1998; 275: G723-G730. PMID: 9756503

86. Kato Y, Kuge K, Kusuhara H, Meier PJ, Sugiyama Y. Gender difference in the urinary excretion of organic anions in rats. $J$ Pharmacol Exp Ther. 2002; 302: 483-489. PMID: 12130705 doi: 10.1124 jpet.102.033878 
87. Lu H, Klaassen C. Gender differences in mRNA expression of ATP-binding cassette efflux and bile acid transporters in kidney, liver, and intestine of 5/6 nephrectomized rats. Drug Metab Dispos. 2008; 36: 16-23. PMID: 17855625 doi: 10.1124/dmd.107.014845

88. Zelcer N, Saeki T, Bot I, Kuil A, Borst P. Transport of bile acids in multidrug-resistance-protein 3-overexpressing cells co-transfected with the ileal Na+-dependent bile-acid transporter. Biochem J. 2003; 369: 23-30. PMID: 12220224 doi: 10.1042/bj20021081

89. Rost D, Kopplow K, Gehrke S, et al. Gender-specific expression of liver organic anion transporters in rat. Eur J Clin Invest. 2005; 35: 635-643. PMID: 16178883 doi: 10.1111/j.13652362.2005.01556.X

90. Yamazoe Y, Gong D, Murayama N, Abu-Zeid M, Kato R. Regulation of hepatic cortisol sulfotransferase in rats by pituitary growth hormone. Mol Pharmacol. 1989; 35: 707-712. PMID: 2725475

91. Ogura K, Kajita J, Narihata H, et al. Cloning and sequence analysis of a rat liver cDNA encoding hydroxysteroid sulfotransferase. Biochem Biophys Res Commun. 1989; 165: 168174. PMID: 2590219 doi: 10.1016/0006-291X(89)91050-4

92. Schoemaker MH, Gommans WM, Conde de la Rosa L, et al. Resistance of rat hepatocytes against bile acid-induced apoptosis in cholestatic liver injury is due to nuclear factor-kappa B activation. J Hepatol. 2003; 39: 153-161. PMID: 12873810 doi: 10.1016/S0168-8278(03)00214-9

93. Fickert P, Trauner M, Fuchsbichler A, et al. Oncosis represents the main type of cell death in mouse models of cholestasis. J Hepatol. 2005; 42: 378-385. PMID: 15710221 doi: 10.1016/j.jhep.2004.10.016

94. Gujral JS, Liu J, Farhood A, Jaeschke H. Reduced oncotic necrosis in Fas receptor-deficient C57BL/6J-lpr mice after bile duct ligation. Hepatology. 2004; 40: 998-1007. PMID: 15382126 doi: $10.1002 /$ hep. 1840400431

95. Zhang Y, Hong JY, Rockwell CE, Copple BL, Jaeschke H, Klaassen CD. Effect of bile duct ligation on bile acid composition in mouse serum and liver. Liver Int. 2012; 32: 58-69. PMID: 22098667 doi: 10.1111/j.1478-3231.2011.02662.x

96. Gujral JS, Liu J, Farhood A, Hinson JA, Jaeschke H. Functional importance of ICAM-1 in the mechanism of neutrophilinduced liver injury in bile duct-ligated mice. Am J Physiol Gastrointest Liver Physiol. 2004; 286: G499-G507. PMID: 14563671 doi: 10.1152/ajpgi.00318.2003

97. Gujral JS, Farhood A, Bajt ML, Jaeschke H. Neutrophils aggravate acute liver injury during obstructive cholestasis in bile duct-ligated mice. Hepatology. 2003; 38: 355-363. PMID: 12883479 doi: 10.1053/jhep.2003.50341

98. Tanaka N, Matsubara T, Krausz KW, Patterson AD, Gonzalez FJ. Disruption of phospholipid and bile acid homeostasis in mice with nonalcoholic steatohepatitis. Hepatology. 2012; 56: 118-129. PMID: 22290395 doi: 10.1002/hep.25630

99. Fang N, Yu S, Adams SH, Ronis MJ, Badger TM. Profiling of urinary bile acids in piglets by a combination of enzymatic deconjugation and targeted LC-MRM-MS. J Lipid Res. 2016; 57: 1917-1933. PMID: 27538824 doi: 10.1194/jlr.D069831

100. Bergström S, Danielsson H, Goransson A. On the bile acid metabolism in the pig Bile acids and steroids 81. Acta Chem Scand. 1959; 13: 776-783. doi: 10.3891/acta.chem. scand.13-0776
101. Gelineau-van Waes J, Voss KA, Stevens VL, Speer MC, Riley RT. Maternal fumonisin exposure as a risk factor for neural tube defects. Adv Food Nutr Res. 2009; 56: 145-181. PMID: 19389609 doi: 10.1016/S1043-4526(08)00605-0

102. Wang E, Norred WP, Bacon CW, Riley RT, Merrill AH Jr. Inhibition of sphingolipid biosynthesis by fumonisins. Implications for diseases associated with Fusarium moniliforme. $J$ Biol Chem. 1991; 266: 14486-14490. PMID: 1860857

103. Schmidt K, Schrader M, Kern HF, Kleene R. Regulated apical secretion of zymogens in rat pancreas. Involvement of the glycosylphosphatidylinositol-anchored glycoprotein GP-2, the lectin ZG16p, and cholesterol-glycosphingolipid-enriched microdomains. J Biol Chem. 2001; 276: 14315-14323. PMID: 11152672 doi: $10.1074 /$ jbc.M006221200

104. Enongene EN, Sharma RP, Bhandari N, Voss KA, Riley RT. Disruption of sphingolipid metabolism in small intestines, liver and kidney of mice dosed subcutaneously with fumonisin B(1). Food Chem Toxicol. 2000; 38: 793-799. PMID: 10930700 doi: 10.1016/S0278-6915(00)00065-X

105. Miyake Y, Kozutsumi Y, Nakamura S, Fujita T, Kawasaki T. Serine palmitoyltransferase is the primary target of a sphingosine-like immunosuppressant, ISP-1/myriocin. Biochem Biophys Res Commun. 1995; 211: 396-403. PMID: 7794249 doi: 10.1006/bbrc.1995.1827

106. Clapham DE. Calcium signaling. Cell. 2007; 131: 1047-1058. PMID: 18083096 doi: 10.1016/j.cell.2007.11.028

107. Jefferson AB, Schulman H. Sphingosine inhibits calmodulindependent enzymes. J Biol Chem. 1988; 263: 15241-15244. PMID: 2844804

108. Zheng W, Kollmeyer J, Symolon H, et al. Ceramides and other bioactive sphingolipid backbones in health and disease: lipidomic analysis, metabolism and roles in membrane structure, dynamics, signaling and autophagy. Biochim Biophys Acta. 2006; 1758: 1864-1884.

109. Levy M, Futerman AH. Mammalian ceramide synthases. IUBMB Life. 2010; 62: 347-356. PMID: 20222015

110. Mullen TD, Hannun YA, Obeid LM. Ceramide synthases at the centre of sphingolipid metabolism and biology. Biochem J. 2012; 441: 789-802. PMID: 22248339 doi: 10.1042/ BJ20111626

111. Laviad EL, Albee L, Pankova-Kholmyansky I, et al. Characterization of ceramide synthase 2: tissue distribution, substrate specificity, and inhibition by sphingosine 1-phosphate. J Biol Chem. 2008; 283: 5677-5684. PMID: 18165233

112. Cingolani F, Futerman AH, Casas J. Ceramide synthases in biomedical research. Chem Phys Lipids. 2016; 197: 25-32. PMID: 26248326 doi: 10.1016/j.chemphyslip.2015.07.026

113. Riebeling C, Allegood JC, Wang E, Merrill AH Jr, Futerman AH. Two mammalian longevity assurance gene (LAG1) family members, trh1 and trh4, regulate dihydroceramide synthesis using different fatty acyl-CoA donors. $J$ Biol Chem. 2003; 278: 43452-43459. PMID: 12912983 doi: 10.1074/jbc. M307104200

114. Imgrund S, Hartmann D, Farwanah H, et al. Adult ceramide synthase 2 (CERS2)-deficient mice exhibit myelin sheath defects, cerebellar degeneration, and hepatocarcinomas. $J$ Biol Chem. 2009; 284: 33549-33560. PMID: 19801672 doi: 10.1074/jbc.M109.031971 
115. Pewzner-Jung Y, Park H, Laviad EL, et al. A critical role for ceramide synthase 2 in liver homeostasis: I. alterations in lipid metabolic pathways. J Biol Chem. 2010; 285: 10902-10910. PMID: 20110363 doi: 10.1074/jbc.M109.077594

116. Basnakian AG, Ueda N, Hong X, Galitovsky VE, Yin X, Shah SV. Ceramide synthase is essential for endonuclease-mediated death of renal tubular epithelial cells induced by hypoxiareoxygenation. Am J Physiol Renal Physiol. 2005; 288: F308F314. PMID: 15479855 doi: 10.1152/ajprenal.00204.2004

117. Boslem E, Meikle PJ, Biden TJ. Roles of ceramide and sphingolipids in pancreatic $\beta$-cell function and dysfunction. Islets. 2012; 4: 177-187. PMID: 22847494 doi: 10.4161/is1.20102

118. Gopee NV, Sharma RP. The mycotoxin fumonisin B1 transiently activates nuclear factor-kappaB, tumor necrosis factor alpha and caspase 3 via protein kinase Calpha-dependent pathway in porcine renal epithelial cells. Cell Biol Toxicol. 2004; 20: 197-212. PMID: 15499968 doi: 10.1023/B:CB TO.0000038458.39516.40

119. Seefelder W, Humpf HU, Schwerdt G, Freudinger R, Gekle M. Induction of apoptosis in cultured human proximal tubule cells by fumonisins and fumonisin metabolites. Toxicol Appl Pharmacol. 2003; 192: 146-153. PMID: 14550748 doi: 10.1016/S0041-008X(03)00262-X

120. Wang DQ, Carey MC. Complete mapping of crystallization pathways during cholesterol precipitation from model bile: influence of physical-chemical variables of pathophysiologic relevance and identification of a stable liquid crystalline state in cold, dilute and hydrophilic bile salt-containing systems. $J$ Lipid Res. 1996; 37: 606-630. PMID: 8728323

121. Bourgès M, Small DM, Dervichian DG. Biophysics of lipid associations. 3. The quaternary systems lecithin-bile saltcholesterol-water. Biochim Biophys Acta. 1967; 144: 189-201. PMID: 6064602

122. Javitt NB, Emerman S. Effect of sodium taurolithocholate on bile flow and bile acid exeretion. J Clin Invest. 1968; 47: 1002-1014. PMID: 5645847 doi: 10.1172/JCI105790

123. Johnson DR, Habeebu SS, Klaassen CD. Increase in bile flow and biliary excretion of glutathione-derived sulfhydryls in rats by drug-metabolizing enzyme inducers is mediated by multidrug resistance protein 2. Toxicol Sci. 2002; 66: 16-26. PMID: 11861969 doi: 10.1093/toxsci/66.1.16

124. Shi Y, Burn P. Lipid metabolic enzymes: emerging drug targets for the treatment of obesity. Nat Rev Drug Discov. 2004; 3: 695-710. PMID: 15286736

125. Cornell RB, Ridgway ND. CTP:phosphocholine cytidylyltransferase: Function, regulation, and structure of an amphitropic enzyme required for membrane biogenesis. Prog Lipid Res. 2015; 59: 147-171. PMID: 26165797 doi: 10.1016/j.plipres.2015.07.001

126. Chen BB, Mallampalli RK. Calmodulin binds and stabilizes the regulatory enzyme, CTP: phosphocholine cytidylyltransferase. J Biol Chem. 2007; 282: 33494-33506. PMID: 17804406 doi: 10.1074/jbc.M706472200

127. Sohal PS, Cornell RB. Sphingosine inhibits the activity of rat liver CTP:phosphocholine cytidylyltransferase. J Biol Chem. 1990; 265: 11746-11750. PMID: 2164014

128. Ryan AJ, Fisher K, Thomas CP, Mallampalli RK. Transcriptional repression of the CTP:phosphocholine cytidylyltransferase gene by sphingosine. Biochem J. 2004; 382: 741-750. PMID: 15139854 doi: 10.1042/BJ20040105
129. Jacobs RL, Devlin C, Tabas I, Vance DE. Targeted deletion of hepatic CTP:phosphocholine cytidylyltransferase alpha in mice decreases plasma high density and very low density lipoproteins. J Biol Chem. 2004; 279: 47402-47410. PMID: 15331603

130. Verkade HJ, Havinga R, Shields DJ, et al. The phosphatidylethanolamine N-methyltransferase pathway is quantitatively not essential for biliary phosphatidylcholine secretion. J Lipid Res. 2007; 48: 2058-2064. PMID: 17595447 doi: 10.1194/j1r. M700278-JLR200

131. Walkey CJ, Yu L, Agellon LB, Vance DE. Biochemical and evolutionary significance of phospholipid methylation. J Biol Chem. 1998; 273: 27043-27046. PMID: 9765216

132. Li Z, Agellon LB, Vance DE. Phosphatidylcholine homeostasis and liver failure. J Biol Chem. 2005; 280: 37798-37802. PMID: 16144842 doi: 10.1074/jbc.M508575200

133. Badiani K, Byers DM, Cook HW, Ridgway ND. Effect of fumonisin B1 on phosphatidylethanolamine biosynthesis in Chinese hamster ovary cells. Biochim Biophys Acta. 1996; 1304: 190-196. PMID: 8982265 doi: 10.1016/S00052760(96)00119-1

134. Zhi J, Mulligan TE, Hauptman JB. Long-term systemic exposure of orlistat, a lipase inhibitor, and its metabolites in obese patients. J Clin Pharmacol. 1999; 39: 41-46. PMID: 9987699 doi: $10.1177 / 00912709922007543$

135. Lucas CP, Boldrin MN, Reaven GM. Effect of orlistat added to diet (30\% of calories from fat) on plasma lipids, glucose, and insulin in obese patients with hypercholesterolemia. $\mathrm{Am}$ J Cardiol. 2003; 91: 961-964. PMID: 12686336 doi: 10.1016/ S0002-9149(03)00112-7

136. Gelderblom WC, Smuts CM, Abel S, et al. Effect of fumoni$\sin \mathrm{B} 1$ on the levels and fatty acid composition of selected lipids in rat liver in vivo. Food Chem Toxicol. 1997; 35: 647-656. PMID: 9301647 doi: 10.1016/S0278-6915(97)00036-7

137. Bollag W, Gallico E. The effect of DL-ethionine on the content of some enzymes in pancreas and liver. Biochim Biophys Acta. 1952; 9: 193-198. PMID: 12977803 doi: 10.1016/00063002(52)90146-7

138. Farber E, Corban MS. Sex difference in ethionine inhibition of hepatic protein synthesis. J Biol Chem. 1958; 233: 625630. PMID: 13575425

139. Koike H, Steer ML, Meldolesi J. Pancreatic effects of ethionine: blockade of exocytosis and appearance of crinophagy and autophagy precede cellular necrosis. Am J Physiol. 1982; 242: G297-G307. PMID: 7065251

140. Lombardi B, Rao NK. Acute hemorrhagic pancreatic necrosis in mice. Influence of the age and sex of the animals and of dietary ethionine, choline, methionine, and adenine sulfate. Am J Pathol. 1975; 81: 87-100. PMID: 1180334

141. Gilliland L, Steer ML. Effects of ethionine on digestive enzyme synthesis and discharge by mouse pancreas. Am J Physiol. 1980; 239: G418-G426. PMID: 6159794

142. Tessitore L, Sesca E, Greco M, Pani P, Dianzani MU. Sexually differentiated response to choline in choline deficiency and ethionine intoxication. Int J Exp Pathol. 1995; 76: 125-129. PMID: 7786762 
143. Fullerton FR, Greenman DL, Blaydes BS, Poirier LA Ethynylestradiol protection against methyl insufficiency in castrated male Wistar/Furth rats fed a methionine-cholinedeficient diet. Carcinogenesis. 1993; 14: 1237-1240. PMID: 8508512 doi: 10.1093/carcin/14.6.1237

144. Scheele G, Jacoby R. Proteolytic processing of presecretory proteins is required for development of biological activities in pancreatic exocrine proteins. J Biol Chem. 1983; 258: 20052009. PMID: 6337149

145. Rinderknecht H. Activation of pancreatic zymogens. Normal activation, premature intrapancreatic activation, protective mechanisms against inappropriate activation. Dig Dis Sci. 1986; 31: 314-321. PMID: 2936587 doi: 10.1007/BF01318124

146. Simpson MV, Farber E, Tarver H. Studies on ethionine 1. inhibition of protein synthesis in intact animals. $J$ Biol Chem. 1950; 182: 81-90.

147. Mato JM, Martínez-Chantar ML, Lu SC. Methionine metabolism and liver disease. Annu Rev Nutr. 2008; 28: 273-293. PMID: 18331185 doi: 10.1146/annurev.nutr.28.061807.155438

148. Antonissen G, Van Immerseel F, Pasmans F, et al. The mycotoxins deoxynivalenol and fumonisins alter the extrinsic component of intestinal barrier in broiler chickens. J Agric Food Chem. 2015; 63: 10846-10855. PMID: 26632976 doi: 10.1021/acs.jafc.5b04119

149. Longnecker DS. Abnormal methyl metabolism in pancreatic toxicity and diabetes. $J$ Nutr. 2002; 132(Suppl): 2373S-2376S. PMID: 12163695

150. Richmond BL, Boileau AC, Zheng S, et al. Compensatory phospholipid digestion is required for cholesterol absorption in pancreatic phospholipase A(2)-deficient mice. Gastroenterology. 2001; 120: 1193-1202. PMID: 11266383 doi: 10.1053/gast.2001.23254

151. Li JP, Chang TM, Wagner D, Chey WY. Pancreatic phospholipase A2 from the small intestine is a secretin-releasing factor in rats. Am J Physiol Gastrointest Liver Physiol. 2001; 281: G526-G532. PMID: 11447033

152. Chang TM, Chang CH, Wagner DR, Chey WY. Porcine pancreatic phospholipase A2 stimulates secretin release from secretin-producing cells. J Biol Chem. 1999; 274: 10758-10764. PMID: 10196148 doi: 10.1074/jbc.274.16.10758

153. Yagami T, Yamamoto Y, Koma H. The role of secretory phospholipase $\mathrm{A}_{2}$ in the central nervous system and neurological diseases. Mol Neurobiol. 2014; 49: 863-876. PMID: 24113843 doi: 10.1007/s12035-013-8565-9

154. Pan Y, Wan J, Liu Y, et al. sPLA2 IB induces human podocyte apoptosis via the M-type phospholipase A2 receptor. Sci Rep. 2014; 4: 6660. PMID: 25335547

155. Murakami M, Taketomi Y, Miki Y, Sato H, Yamamoto K, Lambeau G. Emerging roles of secreted phospholipase A2 enzymes: the 3rd edition. Biochimie. 2014; 107 Pt A: 105-113.

156. Koo SI, Henderson DA, Algilani K, Norvell JE. Effect of marginal zinc deficiency on the morphological characteristics of intestinal nascent chylomicrons and distribution of soluble apoproteins of lymph chylomicrons. Am J Clin Nutr. 1985; 42: 671-680. PMID: 4050727

157. Nassir F, Blanchard RK, Mazur A, Cousins RJ, Davidson NO. Apolipoprotein B mRNA editing is preserved in the intestine and liver of zinc-deficient rats. $J$ Nutr. 1996; 126: 860-864. PMID: 8613888
158. Schwartz R, Topley M, Russell JB. Effect of tricarballylic acid, a nonmetabolizable rumen fermentation product of trans-aconitic acid, on $\mathrm{Mg}, \mathrm{Ca}$ and $\mathrm{Zn}$ utilization of rats. $J$ Nutr. 1988; 118: 183-188. PMID: 3339476

159. Koo SI, Turk DE. Effect of zinc deficiency on intestinal transport triglyceride in the rat. J Nutr. 1977; 107: 909-919. PMID: 192862

160. Fujita M, Jigami Y. Lipid remodeling of GPI-anchored proteins and its function. Biochim Biophys Acta. 2008; 1780: 410-420.

161. Yu S, Michie SA, Lowe AW. Absence of the major zymogen granule membrane protein, GP2, does not affect pancreatic morphology or secretion. J Biol Chem. 2004; 279: 50274 50279. PMID: 15385539

162. Stevens VL, Tang J. Fumonisin B1-induced sphingolipid depletion inhibits vitamin uptake via the glycosylphosphatidylinositol-anchored folate receptor. J Biol Chem. 1997; 272: 18020-18025. PMID: 9218430

163. Chatterjee S, Smith ER, Hanada K, Stevens VL, Mayor S. GPI anchoring leads to sphingolipid-dependent retention of endocytosed proteins in the recycling endosomal compartment. EMBO J. 2001; 20: 1583-1592. PMID: 11285223 doi: 10.1093/emboj/20.7.1583

164. Voss KA, Riley R. T., Gelineau-van Waes J. Trends in fumonisin research: Recent studies on the developmental effects of fumonisins and Fusarium verticillioides. Mycotoxins. 2005; 55: 91-100. doi: 10.2520/myco.55.91

165. Blom HJ, Smulders Y. Overview of homocysteine and folate metabolism. With special references to cardiovascular disease and neural tube defects. J Inherit Metab Dis. 2011; 34: 75-81. PMID: 20814827 doi: 10.1007/s10545-010-9177-4

166. Yamazoe Y, Yamada T, Mitsumori K. Embryo- and testicular-toxicities of methoxyacetate and the related: a review on possible roles of one-carbon transfer and histone modification. Food Safety. 2015; 3: 92-107. doi: 10.14252/foodsafetyfscj. 2015013

167. Locasale JW. Serine, glycine and one-carbon units: cancer metabolism in full circle. Nat Rev Cancer. 2013; 13: 572-583. PMID: 23822983 doi: 10.1038/nrc3557

168. Voss KA, Riley RT, Gelineau-van Waes J. Fumonisin B $\square$ induced neural tube defects were not increased in $\mathrm{LM} / \mathrm{Bc}$ mice fed folate-deficient diet. Mol Nutr Food Res. 2014; 58: 1190 1198. PMID: 24585430 doi: 10.1002/mnfr.201300720

169. Allen RH, Seetharam B, Podell E, Alpers DH. Effect of proteolytic enzymes on the binding of cobalamin to $\mathrm{R}$ protein and intrinsic factor. In vitro evidence that a failure to partially degrade $\mathrm{R}$ protein is responsible for cobalamin malabsorption in pancreatic insufficiency. J Clin Invest. 1978; 61: 47-54. PMID: 22556 doi: 10.1172/JCI108924

170. Marcoullis G, Parmentier Y, Nicolas JP, Jimenez M, Gerard P. Cobalamin malabsorption due to nondegradation of $\mathrm{R}$ proteins in the human intestine. Inhibited cobalamin absorption in exocrine pancreatic dysfunction. J Clin Invest. 1980; 66: 430-440. PMID: 7400324 doi: 10.1172/JCI109873

171. Guéant JL, Champigneulle B, Gaucher P, Nicolas JP. Malabsorption of vitamin B12 in pancreatic insufficiency of the adult and of the child. Pancreas. 1990; 5: 559-567. PMID: 2235967 doi: 10.1097/00006676-199009000-00011 
172. Surtees R, Leonard J, Austin S. Association of demyelination with deficiency of cerebrospinal-fluid S-adenosylmethionine in inborn errors of methyl-transfer pathway. Lancet. 1991; 338: 1550-1554. PMID: 1683972 doi: 10.1016/01406736(91)92373-A

173. Baumann N, Pham-Dinh D. Biology of oligodendrocyte and myelin in the mammalian central nervous system. Physiol Rev. 2001; 81: 871-927. PMID: 11274346

174. Sherman DL, Brophy PJ. Mechanisms of axon ensheathment and myelin growth. Nat Rev Neurosci. 2005; 6: 683-690. PMID: 16136172 doi: 10.1038/nrn1743

175. Mackenzie PI, Bock KW, Burchell B, et al. Nomenclature update for the mammalian UDP glycosyltransferase (UGT) gene superfamily. Pharmacogenet Genomics. 2005; 15: 677-685. PMID: 16141793 doi: 10.1097/01.fpc.0000173483.13689.56

176. Becker I, Wang-Eckhardt L, Yaghootfam A, Gieselmann V, Eckhardt M. Differential expression of (dihydro) ceramide synthases in mouse brain: oligodendrocyte-specific expression of CerS2/Lass2. Histochem Cell Biol. 2008; 129: 233241. PMID: 17901973 doi: 10.1007/s00418-007-0344-0

177. Carmody DP, Dunn SM, Boddie-Willis AS, DeMarco JK, Lewis M. A quantitative measure of myelination development in infants, using MR images. Neuroradiology. 2004; 46: 781-786. PMID: 15243725 doi: 10.1007/s00234-004-1241-z

178. Caballero F, Fernández A, Matías N, et al. Specific contribution of methionine and choline in nutritional nonalcoholic steatohepatitis: impact on mitochondrial S-adenosyl-L-methionine and glutathione. J Biol Chem. 2010; 285: 18528-18536. PMID: 20395294

179. Nelson GJ. The lipid composition of normal mouse liver. $J$ Lipid Res. 1962; 3: 256-262.

180. He Q, Suzuki H, Sharma RP. S-adenosylmethionine or 5'-methylthioadenosine are unable to prevent fumonisin B1 hepatotoxicity in mice despite increased oxidation in liver. $J$ Appl Toxicol. 2006; 26: 509-516. PMID: 17080400 doi: 10.1002/ jat. 1170

181. Fitzhugh OG, Nelson AA. Liver tumors in rats fed thiourea or thioacetamide. Science. 1948; 108: 626-628. PMID: 17783352 doi: $10.1126 /$ science.108.2814.626

182. Swapna I, Kumar KV, Reddy PV, Murthy CR, Reddanna P, Senthilkumaran B. Phospholipid and cholesterol alterations accompany structural disarray in myelin membrane of rats with hepatic encephalopathy induced by thioacetamide. Neurochem Int. 2006; 49: 238-244. PMID: 16519962 doi: 10.1016/j.neuint.2006.01.012

183. Osada J, Aylagas H, Sanchez-Vegazo I, Gea T, Millan I, Palacios-Alaiz E. Effect of S-adenosyl-L-methionine on thioacetamide-induced liver damage in rats. Toxicol Lett. 1986; 32: 97-106. PMID: 3738936 doi: 10.1016/0378-4274(86)90054-8

184. Huang ZZ, Mato JM, Kanel G, Lu SC. Differential effect of thioacetamide on hepatic methionine adenosyltransferase expression in the rat. Hepatology. 1999; 29: 1471-1478. PMID: 10216131 doi: 10.1002/hep.510290525
185. Sutter BM, Wu X, Laxman S, Tu BP. Methionine inhibits autophagy and promotes growth by inducing the SAM-responsive methylation of PP2A. Cell. 2013; 154: 403-415. PMID: 23870128 doi: 10.1016/j.cell.2013.06.041

186. Gukovskaya AS, Gukovsky I. Autophagy and pancreatitis. Am J Physiol Gastrointest Liver Physiol. 2012; 303: G993G1003. PMID: 22961802 doi: 10.1152/ajpgi.00122.2012

187. Perera RM, Stoykova S, Nicolay BN, et al. Transcriptional control of autophagy-lysosome function drives pancreatic cancer metabolism. Nature. 2015; 524: 361-365. PMID: 26168401 doi: 10.1038/nature14587

188. Spassieva SD, Mullen TD, Townsend DM, Obeid LM. Disruption of ceramide synthesis by CerS2 down-regulation leads to autophagy and the unfolded protein response. Biochem J. 2009; 424: 273-283. PMID: 19728861 doi: 10.1042/ BJ20090699

189. Schworer CM, Shiffer KA, Mortimore GE. Quantitative relationship between autophagy and proteolysis during graded amino acid deprivation in perfused rat liver. $J$ Biol Chem. 1981; 256: 7652-7658. PMID: 7019210

190. Huitema K, van den Dikkenberg J, Brouwers JF, Holthuis JC. Identification of a family of animal sphingomyelin synthases. EMBO J. 2004; 23: 33-44. PMID: 14685263 doi: 10.1038/ sj.emboj.7600034

191. van Helvoort A, van't Hof W, Ritsema T, Sandra A, van Meer G. Conversion of diacylglycerol to phosphatidylcholine on the basolateral surface of epithelial (Madin-Darby canine kidney) cells. Evidence for the reverse action of a sphingomyelin synthase. J Biol Chem. 1994; 269: 1763-1769. PMID: 8294425

192. Ternes P, Brouwers JF, van den Dikkenberg J, Holthuis JC. Sphingomyelin synthase SMS2 displays dual activity as ceramide phosphoethanolamine synthase. J Lipid Res. 2009; 50: 2270-2277. PMID: 19454763 doi: 10.1194/jlr.M900230JLR200

193. Tafesse FG, Ternes P, Holthuis JC. The multigenic sphingomyelin synthase family. J Biol Chem. 2006; 281: 2942129425. PMID: 16905542 doi: 10.1074/jbc.R600021200

194. Xu Z, Zhou J, McCoy DM, Mallampalli RK. LASS5 is the predominant ceramide synthase isoform involved in de novo sphingolipid synthesis in lung epithelia. J Lipid Res. 2005; 46: 1229-1238. PMID: 15772421 doi: 10.1194/jlr.M500001JLR200

195. van der Veen JN, Lingrell S, Vance DE. The membrane lipid phosphatidylcholine is an unexpected source of triacylglycerol in the liver. J Biol Chem. 2012; 287: 23418-23426. PMID: 22610093 doi: 10.1074/jbc.M112.381723

196. Pewzner-Jung Y, Brenner O, Braun S, et al. A critical role for ceramide synthase 2 in liver homeostasis: II. insights into molecular changes leading to hepatopathy. J Biol Chem. 2010; 285: 10911-10923. PMID: 20110366 